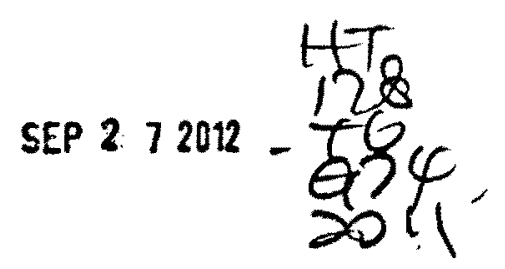

PLACING THE PLANNER IN THE GENTRIFICATION DISCUSSION:

PLANNING INTERVENTIONS IN TORONTO'S DOWNTOWN WEST

by

Anthony F. Greenberg, B.A. Hons. University of Winnipeg, 2008

\author{
A Major Research Paper \\ presented to Ryerson University \\ in partial fulfillment of the requirements for the degree of \\ Master of Planning \\ in \\ Urban Development \\ Toronto, Ontario, Canada, 2011
}

PROPERTY OF
RYERSON UNYWEPSTY LIGAARY

(C) Anthony Greenberg, 2011 


\section{Author's Declaration}

I hereby declare that I am the sole author of this major research paper.

I authorize Ryerson University to lend this paper to other institutions or individuals for the purpose of scholarly research.

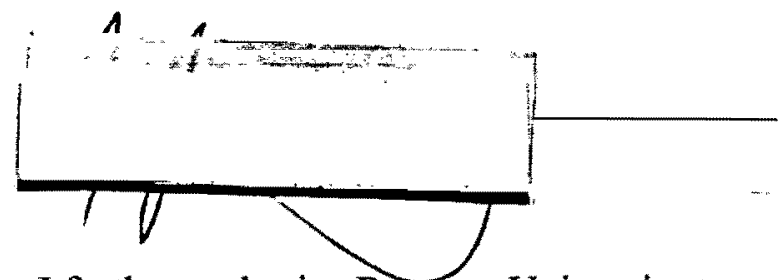

I further authorize Ryerson University to reproduce this paper by photocopying or by other means, in total or in part, at the request of other institutions or individuals for the purpose of scholarly research.

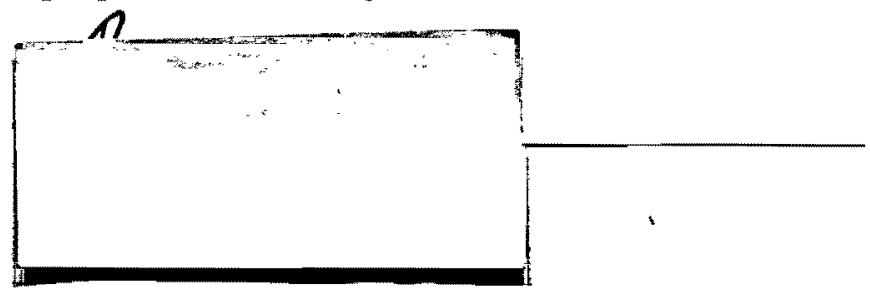




\title{
PLACING THE PLANNER IN THE GENTRIFICATION DISCUSSION: PLANNING INTERVENTIONS IN TORONTO'S DOWNTOWN WEST
}

(C) Anthony F. Greenberg, 2011

\author{
Master of Planning \\ in \\ Urban Development \\ Ryerson University
}

\begin{abstract}
While the process of gentrification has been one of the most hotly debated in academia, this discussion has been dominated by select voices and disciplines. Little has been written from the point of view of the urban planner or explicitly regarding built form and land use. This study firmly situates the planner in the gentrification discussion by analyzing three planning interventions in Toronto's Downtown West. The study's purpose is to provide a clearer understanding of the planner's role and abilities when planning for neighbourhoods facing upscale change. In addition to the case studies, the study provides a general overview of the historical gentrification literature, highlighting what aspects the planner ought to be most concerned about. The study concludes by providing a summary of the inventory of the tools used by the planner in these cases, as well as challenges, problems, and opportunities raised by these cases.
\end{abstract}

KEY WORDS: gentrification, planning, Toronto, urban development 


\section{ACKNOWLEDGMENTS}

I would like to thank a number of people who contributed to the completion of this paper.

First, thank you to Dr. Steven Webber, my project supervisor, who has faithfully stuck with me throughout this process. Thanks to him for allowing me to work with my strengths and to help me with my weaknesses, for always allowing me to "think out loud" in his office as a means to better elucidate my work for the both of us.

Great thanks to Dr. Beth Moore Milroy, my second reader, for her help in the many stages of my process, and for her own work, which has heavily influenced my approach to research.

Thank you to Harold Madi of the Planning Partnership for taking the time out of his busy schedule to speak with me about his and my work, and who has helped develop a better understanding of, and new appreciation for, the power of urban design.

Thank you to those not formally involved in this process but who have helped my intellectual development in one way or another: Dr. Pamela Robinson, for taking the time to meet with me to discuss both my paper and my own professional path, and who constantly encourages me to "think like a planner"; Nina-Marie Lister, whose teaching and work has without doubt heavily affected the way I think about planning, urbanism, and landscape; and finally, Erin Tito, my colleague and intellectual "soul mate" who has relentlessly fueled my fire and who, through our endless discussions about what it is about cities we love so much, has re-affirmed again and again the reason I chose to go into urban planning in the first place. I hope this program has only been the beginning of our professional partnership!

Finally, thanks to my mother and father for supporting me throughout my childhood and adulthood, particularly my decision to return to graduate school to pursue a brand new chapter of my life. Specifically, to my mother Annalee: it has not gone for granted that having a professional editor for a mother has been of great benefit to me as a student. Thank you for taking the time throughout my two degrees to read my work.

Thanks to all. I sincerely hope you enjoy reading this study. 


\section{Table of Contents}

I. Introduction p. 1

Structure of Study $\quad$ p. 3

II. Gentrification Scholarship: A Review p. 5

What Is Gentrification? p. 5

Gentrification \& the State $\quad$ p. 8

III. Gentrification \& the Planner p. 10

Gentrification Versus Revitalization p. 11

What the Planner Ought to Be Concerned About p. 13

IV. Case Study: Toronto's Downtown West p. 19

A. Ossington Avenue Restaurant Study \& Queen Street West

Restaurant Study

p. 23

B. The West Queen West Triangle p. 28

The Protection of a Creative Nucleus p. 32

Temporal Issues and the Need for Anticipatory \& Preemptive Plans p. 36

C. The West Queen West BIA's Urban Development

Framework

p. 39

The West Queen West BIA p. 40

BIAs \& the Development Process p. 42

The West Queen West Development Framework p. 44

Analysis of the Urban Development Guidelines p. 46

V. Case Study Analysis

p. 48

Tools Available p. 48

The Limits of Built Form $\quad$ p. 50

Thoroughness, Fairness, and Community Consultation p. 51

VI. Conclusion

p. 54

References

p. 56 


\section{Figures}

i. Map of Central Toronto

p. 20

ii. Ossington Restaurant Study Area Boundaries

p. 24

iii. Queen Street West Restaurant Study Area Boundaries

p. 24

iv. Queen West Triangle Boundaries

p. 29

v. West Queen West BIA Boundaries

p. 40

\section{Tables}

i. Study Area Income

p. 19 


\section{Introduction}

Over the past fifty years, the topic of gentrification has been one of the most hotly debated in academia. Since the 1960s, when the term was first coined by Ruth Glass, theorists have argued about what causes it and what effects it has on the urban fabric, decried it as a major social justice issue, and explored how in recent years neo-liberal economics and laissez-faire housing policies have exacerbated the transformation of a process once understood as organic into one that is policy-led. While the gentrification discourse and academic literature is vast, it has been dominated mostly by select voices and disciplines - particularly human and cultural geographers, urban theorists, and political scientists. Though from many perspectives, policy recommendations tend to mostly address larger economic structuring, housing policy, and financial/mortgage mechanisms, while little has been written about built form and land use. While some of the scholars writing on the topic may well be practicing planners, the discussion has had little (visible) contribution from practicing urban planners, and it has not focused on assessing municipal planning processes through the lens of gentrification. This is particularly troublesome considering the accusations in recent work of municipal governments exacerbating the process. How does the planner fit into this discussion?

Toronto, a city that has had its fair share of the spotlight in this canon of academic work, has been undergoing a significant spatial-demographic shift over the past four decades, with the inner city experiencing an influx of higher-income population, and the outer city (often referred to as the inner suburbs) becoming home to predominantly lowincome residents and serving as an immigrant-reception area (a restructuring reflected in other global cities). A recent study by David Hulchanski (2010), comparing demographic 
change from 1970 to 2005 , presents this polarization in a somewhat startling manner with visuals highlighting the extremity of this new patterning, as well as the "disappearance" of the middle class. As such, Hulchanski's study has been met with wide media attention. The report, entitled The Three Cities Within Toronto, recommends considerably more study and improvement of these inner suburbs. With city efforts such as the Tower Renewal Program, it seems planners are aptly responding to this new area of concern. Without doubt, this focus is required. However, I also posit that this study should provide extra motivation for planners and municipal governments to better understand the shift that has occurred in the inner city. Along with the aforementioned absence in the scholarly discussion, it is necessary now more than ever for planners to better understand their role in the gentrification process.

This study's central purpose is to explore the role of the planner in neighbourhood development decisions related to gentrification in a contemporary urban development context. I take a case-study approach to this exploration, conducting an analysis of planning issues in Toronto's Downtown West over the past decade. Using laws and other policy frameworks, municipal and provincial staff reports, as well as media publications, I hope to better elucidate the planner's role and motives throughout the process, as well as inventory the suite of tools related to this process available to land-use planners in Ontario. It is my hope that by exploring these cases, a better understanding (and new questions) will emerge regarding the planner's role in addressing neighbourhood change related to gentrification, particularly in the context of the "neo-liberal" state. Iri addition to making sense of real-life practice, I also attempt with this study to highlight the concerns about the gentrification process as it relates to planning practitioners in a wider 
context - not just Toronto - thus providing a "reference" of sorts in regards to planning for upscale neighbourhood change.

It should be noted that as both the process and the understanding of gentrification has changed over time in response to different political and economic climates, the practice I am examining in my study is not necessarily reflective of how planners have responded to such change in the past. Rather, my exploration is a matter of discovering what these few cases reveal about the planner's role in Toronto's present-day planning climate, using these cases as an opportunity with which to place the planner in the contemporary gentrification discussion.

\section{Structure of Study}

My study begins with a brief history of the scholarly work on gentrification, setting a context in which to place my study of Toronto, and to reveal that the main discussions have been about structural explanations of the process and about its effectsthat little has been written about the relationship between gentrification and the regulation of land use and built form. I then attempt to address this gap, by providing my opinion as to how to situate the planner within the gentrification discussion. In order to contextualize what I will analyze in my case studies and to present the wider reference for what the planner ought to be concerned about in general, I first highlight what specific issues the planner must be concerned about in terms of gentrification. I then begin my profiles and analyses of three separate planning interventions, all within a single geographic area Toronto's Downtown West-that has undergone gentrification in the past two decades. 
The study ends with my analysis: a summary of the tools employed by the planners in the process, as well as other concerns and restraints raised by these cases.

As I will discuss in more detail, how different parties perceive the stage of a neighbourhood in the gentrification process is relative to the different actors involved, and the planning events I examine may be perceived by some to have occurred after the subject lands had already been substantially gentrified. Further, the timing and staging of the individual events in relation to a traditional gentrification process are not always constant. For example, the restaurant upgrading on Ossington \& Queen occurred after residential areas had gentrified; the interest in the West Queen West Triangle developments occurred once artists were already living in adjacent areas. However, what is common among all of the cases in my study is concern from the interested parties in the anticipated use changes associated with gentrification: the influx of higher-income residents (in the case of new condos) and/or tastes as illustrated by the arrival of upscale restaurants, stylish bars, and chain stores that challenge characteristics such as diversity, accessibility, and affordability that had made the neighbourhood desirable in the first place. These are the issues that accompany neighbourhood change in gentrifying and gentrified areas. 


\section{Gentrification Scholarship: A Review}

As stated, the aim of this paper is to evaluate and better understand the planner's response to change in gentrifying neighbourhoods through land-use planning and zoning interventions. While these discrete neighbourhood changes and the planner's response to them might be representative of change that could occur in any sort of neighbourhood (not just those that are gentrifying), it is one of the other purposes of this paper to situate the planner's role in the wider gentrification literature discussion, which has - for the most part - not examined professional planning practice. Yet, before exploring and analyzing how the planner has intervened in the process through practice, I will review the history of scholarship regarding gentrification to contextualize my study within the wider gentrification discussion. While the content of my summary might seem removed from the content of my case studies (which are concerned primarily with issues of built form, land use, and zoning), this review is provided first as a means to show what the traditional scholarship on gentrification has been concerned about. But also, by summarizing these concerns, I can then evaluate if and how the Toronto events I examine address these concerns, and whether or not there are linkages between the planners' practices in my case studies and traditional concerns surrounding gentrification such as affordability, diversity, and equity.

\section{What Is Gentrification?}

The process of gentrification has been defined in different ways at different times, with each new definition reflecting a new understanding of the process (Lees et al., 2010, p. 3). Guided by the many definitions I have read, I choose to define it in the way it 
seems to be most commonly understood and most representative of its contemporary manifestation - that is, as a process of influx of a higher socio-economic class into a previously lower socio-economic neighbourhood, often (but not always) causing displacement. First understood as a marginal urban process relevant to a few major urban centres, the proliferation of the gentrification process continued over time, due to both changing cultural attitudes of the "new middle class" (Ley, 1996) who desire to live in the city, as well as policy-endorsed campaigns to revitalize city centres (Kennedy \& Leonard, 2001).

Early scholarship focused on what is now considered classic (or traditional) gentrification, the renovation and repair of older building stock in aesthetically pleasing historical neighbourhoods (Lees et al, 2010, see Introduction), while the scholarship today has broadened its definition and focus. The concept is now studied in the context of new-build development in central areas (known as "super-gentrification") as well as in mixed-income social housing redevelopment (Lees, 2008; August, 2008).

In the 1970s, the process of gentrification emerged as a topic of interest for two major reasons. First, when the process began, it contradicted previous trends of suburban settlement. Second, specifically among social and community activists, it became a cause for concern due to its detrimental effects on low-income neighbourhoods - primarily because of its displacement of original residents, but also its effects on social cohesion and neighbourhood diversity (Hartman, 1984; Jacobs, 2001; Lees, 2008; Walks and Maraanen, 2008). Displacement can be interpreted to occur in many different ways, in both passive and active forms (Hartman, 1984). For example, residents can literally be evicted from properties when landlords choose to upgrade units or convert them to 
condominiums. Homeowners on limited incomes, unable to afford property tax increases that are a result of increased market value assessments, are displaced (Hartman, 1984). Or finally, as a neighbourhood's commercial spaces are converted to suit the tastes and needs of newer, affluent residents, residents might voluntarily leave a neighbourhood when it no longer fulfills their needs or if they feel socially excluded (Zukin, 2010; Mazer \& Rankin, 2011).

In the 1970s and 1980s, much writing was devoted to understanding the cause of gentrification and pitted two schools of scholars—structuralists and humanists-against each other (Hamnett, 1991). The former generally attached themselves to versions of Neil Smith's (1979) theory of the rent gap. Simply put, gentrification occurs when the gap between current capitalized land rent and potential land rent of a property is large enough that, after rehabilitation, the developer or homeowner can profit (Smith, 1979). Gentrification is thus a phenomenon explained primarily by market dynamics and the capitalist pursuit of profit. The humanist writings, however, focus on the shifting tastes of a new post-industrial middle class whose family structures were changing, and who had a renewed interest in the urban lifestyle and a newfound attraction for historical preservation (Ley, 1996). After nearly two decades of heated debate, scholars became tired of the structuralist-humanist "stalemate" and generally agreed the process of gentrification was best understood as a combination of both perspectives (Lees et al, 2010). In the 1980s, with the rise of post-modern thinking, studies shifted from macrostructure explanations for the cause to more analytical and micro-scaled studies of the phenomenon's effects, often at the neighbourhood level: Studies also became more interdisciplinary, with more thorough studies devoted to culture (Zukin, 1982) and 
identity politics (Castells, 1983; Lauria \& Knopp, 1985; Rose, 1984) in relation to gentrification.

\section{Gentrification \& the State}

In the 1990s, research on gentrification continued. By this point, however, what had been mostly regarded as a niche topic became more widely discussed. Critical theorists began to posit gentrification as one aspect of a wider neo-liberal agenda (Smith, 2002; Harvey 2008). Whereas public policy up until the 1980s had for the most part reflected a "laissez-faire" approach, "to encourage it only if the private market has proven it viable and in some cases, even help in its resistance" (Hackworth \& Smith, 2001), the neo-liberal economic and political climate that emerged in the 1980 s spawned policies that were more conducive to the gentrification process (Hackworth \& Smith, 2001). As more and more responsibilities were downloaded to local government, governments became more reliant on private revenue and public-private partnerships, providing easier access to development in downtown areas through incentives and relaxed zoning. Governments also reduced their protection of affordable housing (Hackworth \& Smith, 2001). In the 2000 s, the emerging trend of mixed-income social housing redevelopment gained traction globally. While redevelopments are lauded as providing increased social mix and are seen as a positive addition to "decaying" neighbourhoods, many have been critical of these projects, arguing that the desired social mix is nothing but a magnet to attract private investment to areas of cities that need the revenue and this new population's presence does not have any social benefits to the areas' original inhabitants (Lees, 2008; August, 2008). As a result of this shifting support, what was once a niche 
phenomenon was now spreading to more and more cities. In major global cities, gentrification posed a major threat to the affordability and diversity of major urban centres. To put it analogically, by the late 1990s, the phenomenon that had once been described as "islands of renewal in a sea of decay" (Berry, 1985), was now better understood as "islands of decay in a sea of renewal" (Wyly \& Hammel, 2009). 


\section{Gentrification \& the Planner}

As just discussed, the process of gentrification has evolved over the past five decades from a marginal, neighbourhood-level process to a state-facilitated phenomenon supported by a broader neo-liberal agenda. The role of the planner is clearly implicated in the process as the profession that develops land-use policy, built-form requirements, and community planning. However, as I found after conducting the preceding literature review, scholarship tended not to mention the urban planner specifically, but rather, municipal governments and policy-makers in general.

The scholarship on gentrification is the product of many disciplines, but perhaps most predominantly comes from human and Marxist geographers and those in urban studies. Even though there is some research that provides policy recommendations to mitigate the negative effects of gentrification, little of the writing has been done by planners themselves, and that raises a problem with linking scholarship/critique to planning practice. Further, most of the policy recommendations are aimed towards higher-level policy makers dealing with affordable housing, not practitioners dealing with built form. However, as the main objective of the planning profession is to create just, complete, and sustainable communities (CIP Code of Practice, 2004), there is benefit to more explicitly explore how the process of gentrification applies to a planner's everyday practice ${ }^{1}$. What this next section intends to do, then, is unpack the often contradictory relationship between the planner and gentrification by discussing what aspects of gentrification are in line with many planning objectives (such as downtown

\footnotetext{
${ }^{1} \mathrm{I}$ acknowledge that there is difficulty in addressing all planners as one entity, and that different planners might have different ideologies or practice methods. However, planners who are members of professional associations across North America adhere to a code of conduct tying them to practice in the interest of the public and with responsibility to natural resources. With these common responsibilities, I justify speaking of "the planner" as a singular entity.
} 
revitalization), and what aspects of gentrification planners ought to be cautious about and take into consideration for daily practice ${ }^{2}$. The first section regarding gentrification and revitalization is provided more as a discussion of the planner in general. Because Toronto itself never faced major downtown disinvestment, this discussion is less applicable to Toronto but is included to address my broader concern of better understanding the role of the planner to the process of gentrification in general. However, the second part of this section concerning what the planner ought to be concerned about very much frames - in addition to my prior literature review—how I evaluate my case studies.

\section{Gentrification Versus Revitalization}

Even before the proliferation of neo-liberal politics and environmental planning that emerged out of the 1980 s, downtown revitalization efforts had been a major focus of many urban centres within North America since the post-World War II years. With postwar suburban development and global economic restructuring, most major American cities experienced mass exoduses from the inner city. These American cities were left with low-income, inner-city neighbourhoods, often characterized by black or Latino ghettos. Canadian cities, specifically Toronto, did not have the mass exodus or ghettos the same way American cities did (see Jane Jacobs' introduction to Sewell, 1993); however, in Canadian cities, the inner city was traditionally home to lower-income residents and acted as immigrant-reception areas (Walks \& Maaranen, 2008, p. 313). With the objective of increasing property tax revenue and reversing the image of a decaying city centre, the latter half of the twentieth century saw many municipal

\footnotetext{
${ }^{2}$ My discussion here is not to suggest that planners do not already have these concerns nor is it to say they have not already practiced in a manner reflecting such concerns. Rather, I am merely attempting to provide a clear list of these concerns.
} 
governments employing major revitalization campaigns to encourage residents to move back into the city, in conjunction with other major developments to "revitalize" the core (Kennedy \& Leonard, 2001).

Glancing at the numerous planning guides published by industry leaders such as the American Planning Association or Urban Land Institute regarding downtown revitalization, as well as Canadian literature devoted to demystifying the strategies to creating lively towns centres (Filion et al, 2004; for an overview, see also Clendening \& Greenberg, 2010) it seems a planning doctrine that a healthy city centre is essential to a great city. The city centre symbolically acts as an indicator for the overall health of a city (Clendening \& Greenberg, 2010). The core is also home to a city's historical centre (both central business district and older residential neighbourhoods), possessing assets of important cultural and historical significance, as well as built form conducive to traditional urban lifestyle, once lauded by the influential Jane Jacobs and adopted in subsequent years by neo-traditional urbanists. Classic planning texts such as William Whyte's City: Rediscovering the Centre (1989) provide the typical explanations of why downtown revitalization matters. Whyte is so adamant about downtown revitalization that there is a chapter in the book entitled "The Case for Gentrification," which states that "the poor" in gentrifying neighbourhoods are hurt more by disinvestment than they are by the new investment from gentrifiers. Beyond the experiential benefits of downtown vitality, once sustainable development became a key focus for city-builders, anti-sprawl movements such as Smart Growth, widely accepted by planners, came to encourage intensification through infill development to achieve maximum usage of central-city neighbourhoods as a means to limit outward development. 
What the Planner Ought to Be Concerned About

If healthy inner cities are considered so vital, why has the process of gentrification faced such resistance? What's the difference between gentrification and revitalization? It can be confusing: is gentrification a pejorative term for revitalization? Or are revitalization, renewal, and urban renaissance "euphemisms" for gentrification (Mazer, 2010)? The answer is, both. Each term is used by different parties either advocating for, or protesting, economic reinvestment in central neighbourhoods. But when is gentrification okay? And when is it problematic? The politics of neighbourhood change are too complicated to categorize gentrification as "good" or "bad", but this section attempts to explain when and where the process is more troublesome than in other places and times, as well as explain what other effects of the process the planner ought to be cautious about.

In "Dealing with Neighbourhood Change: A Primer on Gentrification and Policy Choices" (2001), Kennedy \& Leonard give a thoughtful explanation regarding when gentrification matters most, understanding that different cities are at different levels of development, and that a specific understanding of a regional context is necessary to determine at what point a little bit of gentrification is a good thing, and at what point it becomes a problem. Gentrification is problematic when a city's affordable housing stock is limited and relocation comes at a higher stake to the residents. Jane Jacobs', the late legendary urban writer and activist, has discussed the difference between welcome gentrification that is slow and moderate, supplying needed investment into underserviced areas, and "vicious" and "excessive" gentrification in cities where demand for 
urban living has outrun supply (Jacobs, 2001). Such is the case in Toronto, where the aforementioned report by David Hulchanski reveals that the inner city has become almost predominantly home to high-income residents, the fringes home to lower-income residents, while the middle-income group is disappearing from the city, moving primarily to suburbs outside of its municipal boundaries. These fringes, still within the City of Toronto's boundaries, the inner suburbs, were not built for low-income communities. They are often ill served by transit, and do not possess the services needed by lowincome and new immigrant communities. Toronto's current profile is reflective of most major metropolitan cities that experienced major waves of gentrification in the past decades. However, in contrast to the global cities, most mid-sized cities in Canada and the US still contain swaths of lower-income central neighbourhoods. In these cities, "revitalization" in moderate amounts would be considered welcome.

Beyond understanding this regional context, there are writers (Hartman, 1984; Smith, 1996) who argue that regardless of whether or not there is somewhere else affordable to live, that displacement through neighbourhood upgrading is ethically immoral. There are social elements to neighbourhood belonging that exist outside of economic factors. "The Right to Stay Put," written by Chester Hartman in 1984, still resonates as a fierce defense for a community's right to their home. Whether it's the City of Winnipeg that could benefit from some gentrification in its under-populated downtown core, or the City of Detroit that represents post-industrial decay at its most extreme, just because a city has many affordable places for residents to go does not mean humans and their homes should be treated like objects. Hartman argues that "the right to stay put" should be a basic human right, and he lists the many public benefits to a firmly rooted 
community: safety to person and property, important social ties to neighbours and existing commercial establishments, and greater care for public and private space (Hartman, 1984, p. 302).

Hartman's discussion of the benefits of a rooted community touches on another important issue in gentrified neighbourhoods that not many others have addressed: the upgrading or homogenization of commercial establishments. Most gentrification literature focuses on the residential aspect of gentrification; however, the gentrification process can also greatly change the commercial character of an area as well. Much like residential areas, once a commercial strip has proven popular, rents increase, pushing smaller businesses out, leaving a rental market only international chains and popular businesses can afford (Mintz, 2011). Commercial establishments may be more vulnerable to displacement than residences due to the fact that very few business-owners own their space (Jacobs, 2001). As with residential gentrification, there is no one typical progression of events characterizing the evolution of commercial gentrification, but generally speaking, the businesses serving low-income communities are displaced, as well as the innovative retailers opened by first-stage gentrifiers, such as artists (Rankin, 2008; Jacobs, 2001; Mintz, 2011). What is left is a "monoculture", characterized by international chains, and businesses serving upscale residents (Jacobs, 2001). As Jane Jacobs mentions in a speech from 2001, in comparison to other urban issues such as housing and social services, the topic of commercial change in gentrifying neighbourhoods might appear trivial, and might explain this absence of attention. However, recent studies in the context of gentrification and beyond show the value of maintaining a diversity of local, independent businesses is highly important (Rankin, 
2008; Mazer \& Rankin, 2011; Mitchell, 2006; Zukin \& Kosta, 2004; Zukin, 2010; Jacobs, 2001). First off, a diversified, locally based commercial make-up is generally regarded as contributing to a more sustainable economy (Mitchell, 2006). Second, beyond their obvious direct services to residents, businesses act as important sites of social exchange (Mazer \& Rankin, 2011). Third, local businesses act as a visual signifier of an interesting area that separates one place from the next, contributing to the wider planning objective of "place-making" (Mitchell, 2006).

Of notable importance is Katharine Rankin's (2008) study on commercial gentrification in the context of Toronto in the very same study area as my paperToronto's Downtown West. Rankin conducted a series of interviews with business owners in the neighbourhood who are located on commercial avenues at different points in the gentrification process. A more recent study by Rankin with Katie Mazer (2011) continues this exploration and conducts cognitive mapping with marginalized residents in Parkdale, namely people living with mental illness or rooming house residents, and the area's gentrifiers. One of the most interesting and valuable findings from Rankin's \& Mazer's study is the discovery that original residents remain largely confined to the limited geographical boundary of their neighbourhood for day-to-day needs, whereas gentrifiers, who are more affluent and have greater access to mobility, tend to go outside their neighbourhood. What this means is that the original residents, who are less mobile, benefit from the existing commercial establishments. While neighbourhood change is inevitable, maintaining a mix of businesses that serve different needs and different income brackets should remain a priority for planners (this goes for any neighbourhood, 
gentrifying or non-gentrifying), even if the planner only has the capacity to influence zoning and land use.

Mazer \& Rankin (2011) also speak to the importance of commercial establishments, along with public parks and other public space, as community meeting places that are of social value to a neighbourhood. Mazer \& Rankin discuss how once members of a community are alienated from these basic public places, their sense of belonging diminishes, and living in their neighbourhood is no longer inclusive, leading to possible relocation. Other studies (Teixera, 2007; Hackworth \& Reckers, 2005) suggest that businesses in gentrified areas still serve past residents who have moved elsewhere. For example, although many of the Portuguese immigrants who grew up in the Little Portugal area of Toronto have moved elsewhere, its businesses and institutions still remain a vital part of the diaspora's community in Toronto (Teixera, 2007).

Finally, Kennedy and Leonard (2001), even though they provide the nuanced understanding of city-to-city context and are open to gentrification in certain cases, state that regardless, the goal of city-builders should always be "equitable development": that is, neighbourhood improvement or upgrading that do not bear the cost of displacement or unfair effects on lower-income communities. It should also be noted that equitable development is also at the core of sustainable development under the social aspect of sustainability.

There seems to be a general understanding among all writers on the topic of neighbourhood change that change in users and neighbourhood character is inevitable. For planners, it ought to be a priority to guide this change so it is most equitable for everyone. But as with every planning project juggling the public interest, this is a very 
difficult task. Further, as I will show later in the West Queen West Triangle case, one of the problems with gentrification is that the neighbourhood change is fast-paced and hard to predict. Hopefully, by exploring how planners in the City of Toronto have dealt with change, I can expose how the planner, if at all, can better have a role in guiding this process. 


\section{Case Study: Toronto's Downtown West}

Toronto's Downtown West End is an area typical of those discussed in the gentrification literature. Adjacent to the downtown core, the area is well served by transit and is home to an historical housing stock. The area was traditionally an immigrantreception area in the mid- to late- twentieth century, particularly home to the largest Portuguese population outside of Portugal, as well as many Chinese and Vietnamese residents (Teixera, 2006; City of Toronto, 2003a; City of Toronto, 2003b). The area has undergone significant demographic change over the past decade. Average individual income in my study area has been steadily increasing since 1996 (see Table I). The difference between the average incomes of residents in my study area in relation to the population of Toronto is narrowing, from a ratio of $74 \%$ of city average from 1996 to $90 \%$ of city average in 2006 (Statistics Canada 2007; Statistics Canada 2006; Statistics Canada 1997).

\section{Table I. Study Area Income (Source: Statistics Canada)}

Average Personal Income, 15 years and older

\begin{tabular}{|l|r|r|r|r|}
\hline & \multicolumn{1}{|c|}{ Study Area } & \multicolumn{1}{l|}{ Toronto } & Difference & \multicolumn{1}{l|}{ Ratio } \\
\hline 1996 Census Data & $20,222.06$ & $27,443.44$ & -7221.37 & $74 \%$ \\
\cline { 1 - 1 } 2001 Census Data & $28,978.89$ & 37,833 & $-8,854$ & $77 \%$ \\
\cline { 1 - 1 } 2006 Census Data & $36,205.82$ & 40,376 & -4170.17 & $90 \%$ \\
\hline
\end{tabular}

\% Average Personal Income Increase

\begin{tabular}{|l|r|r|}
\hline $1996-2001$ & Study Area & \multicolumn{1}{|l|}{ Toronto } \\
\hline $2001-2006$ & $43.30 \%$ & $37.90 \%$ \\
$6.70 \%$ \\
\hline
\end{tabular}




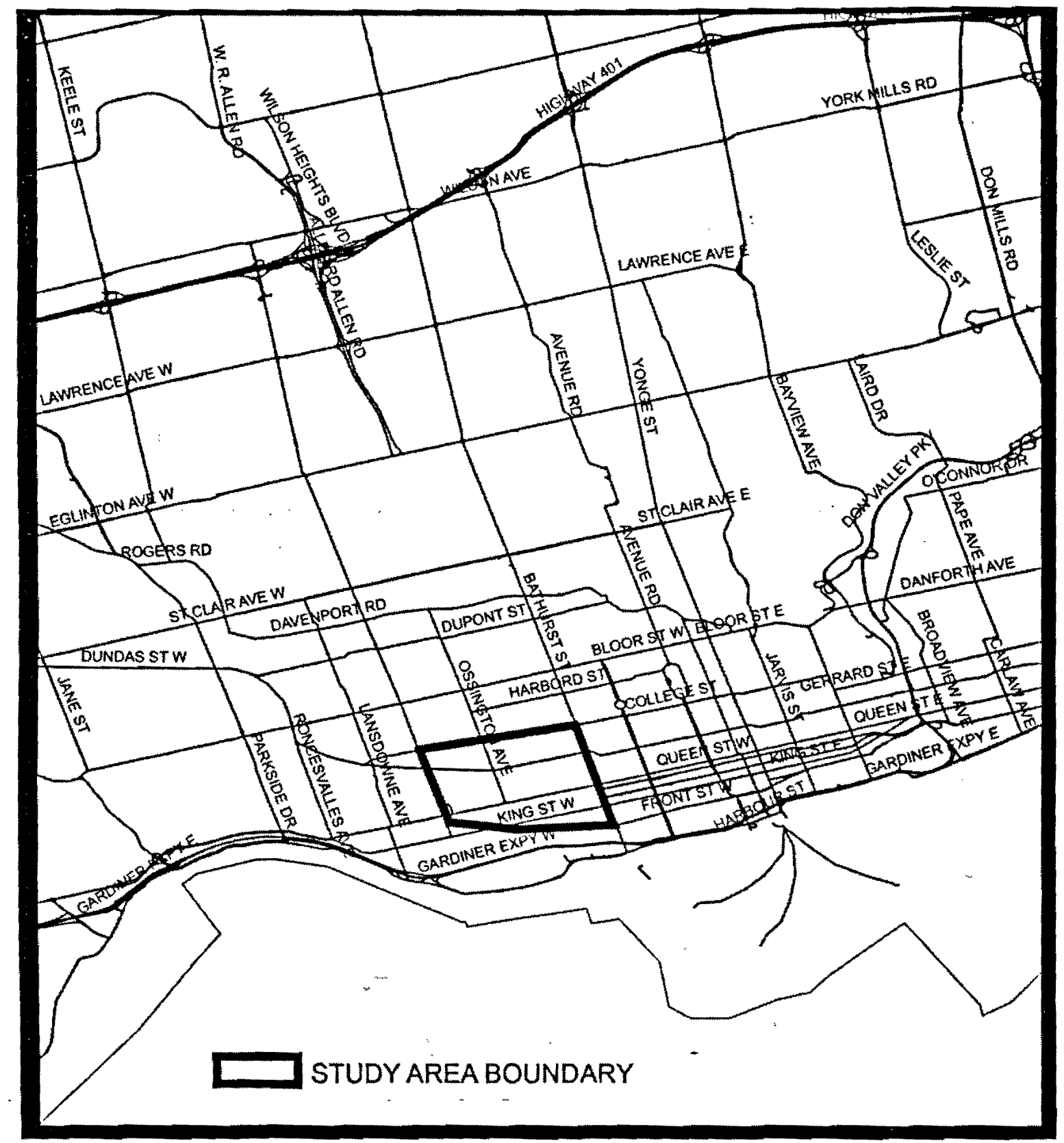

Figure I. Map of Central Toronto (for context only; not to scale)

Lees at al. (2010, see Introduction to Part Two) state there are problems in objectively applying a "stage model" to the gentrification process, as the perception of what stage in the gentrification process a neighbourhood is at is relative to different actors in the process. The gentrification process should be recognized as exactly that, a 
process. However, I posit that at the point this paper is being written, the Downtown West area is, relatively speaking to other areas in the city and if one were to use a traditional stage model, nearly completely gentrified. That is, the early and marginal gentrifiers (artists, LGBT community, single households) have already moved in to the area and made it attractive for slightly more affluent middle-class residents (El Kalache et al., 2005; Texeira, 2007; Statistics Canada, 1997, 2002, and 2007). Today, the area is a mix of original immigrant residents, gentrifiers, converted lofts, and new-build condominiums. Even though the residential make-up might signal that the area is in one of the final stages of the gentrification process, the commercial aspect is still undergoing significant change, and the planning interventions I examine reflect that ${ }^{3}$. The reason I focus my study on this area as opposed to adjacent areas in the city that are in an earlier stage of the gentrification process (such as the area of Parkdale to the west) is that by studying a recently gentrified area, I am able to evaluate planning interventions that have already occurred and been completed. Evaluating interventions that have passed means I can evaluate them in their final stage, with appropriate reflection.

Toronto is an oft-studied city in the wider gentrification literature. Earlier works, such as John Caulfield's City Form and Everyday Life (1994), focused on Toronto's earliest gentrifying neighbourhoods (such as Cabbagetown), while many more contemporary studies focus on my study area, Downtown West. The University of Toronto's Centre for Urban and Community Studies (CUCS) has conducted a number of studies of the area in conjunction with St. Christopher House, a not-for-profit community development organization serving the neighbourhood. Among these are many qualitative

\footnotetext{
${ }^{3}$ In light of this ambiguity and relativity, I herein refer to the Downtown West as a "gentrifying/gentrified" area
} 
studies that have been excellent in providing a micro-level understanding of the politics and needs of residents in the area as well as a statistical context. These studies are valuable for a planner in understanding the social dynamics of gentrification (particularly Carlos Texeira's (2007) study with Portuguese residents in Little Portugal, and Mazer \& Rankin's (2011) recent study with cognitive mapping of residents in Parkdale). However, the CUCS has not conducted any studies in the area in relation to planning policy. Tom Slater's (2004) article titled "Municipal-Managed Gentrification in South Parkdale" critically examines the tightening of rooming-house policy in Parkdale, a traditionally low-income area directly west of my study area. Slater's study situates housing and planning policy as a focus. He concludes that this policy, which he attributes to the city and its planning staff, has facilitated gentrification. To my knowledge, my study is the first to discuss the planner's role in guiding gentrification in a Toronto context.

My study looks at three separate planning interventions/events that have occurred in the study area: the Ossington Avenue Restaurant Study and the Queen West Restaurant Study (treated in my paper as one singular intervention), the city's role in planning for the West Queen West Triangle, and the private sector's role in producing development guidelines. I will first present the three cases with limited commentary, then - after comparing all three together-assess common themes and limitations I have discovered. Once this analysis is complete, I will provide my final discussion as to what can be learned through examining these interventions. 


\section{A. Ossington Avenue Restaurant Study \& Queen Street West Restaurant Study}

Both the Ossington Avenue Restaurant Study and the Queen Street West Restaurant Study were conducted in response to the same concern: conflicts surrounding the opening of many bars on major mixed-use corridors that are directly adjacent to residential neighbourhoods (City of Toronto, 2009a; City of Toronto, 2009b). Such a conflict - new use in previously under-utilized space that is deemed incompatible with surrounding use - is not exclusive to, but characteristic of, gentrifying neighbourhoods. While the change occurring in these two areas might be considered more of an issue of entertainment zones in a residential area (not of gentrification), that the commercial establishments opening were reflective of higher-end clientele and bourgeois tastes situates it as an event worthy of discussion in this context. Further, the issues expressed during the community consultation meetings, particularly the need for diversity and development compatible with the residential area-is characteristic of the concerns with commercial upgrading (Rankin, 2008; Jacobs, 2001).

While both studies emerged out of similar concerns over incompatible use, the Ossington study was conducted under recommendation to council from the planning staff, while the Queen West study was conducted after concerns from residents, particularly the Queen-Beaconsfield Residents Association and Active 18, the latter of which were also heavily involved in the Queen West Triangle developments later discussed in this paper (City of Toronto, 2009b). The residents provided the city with a 


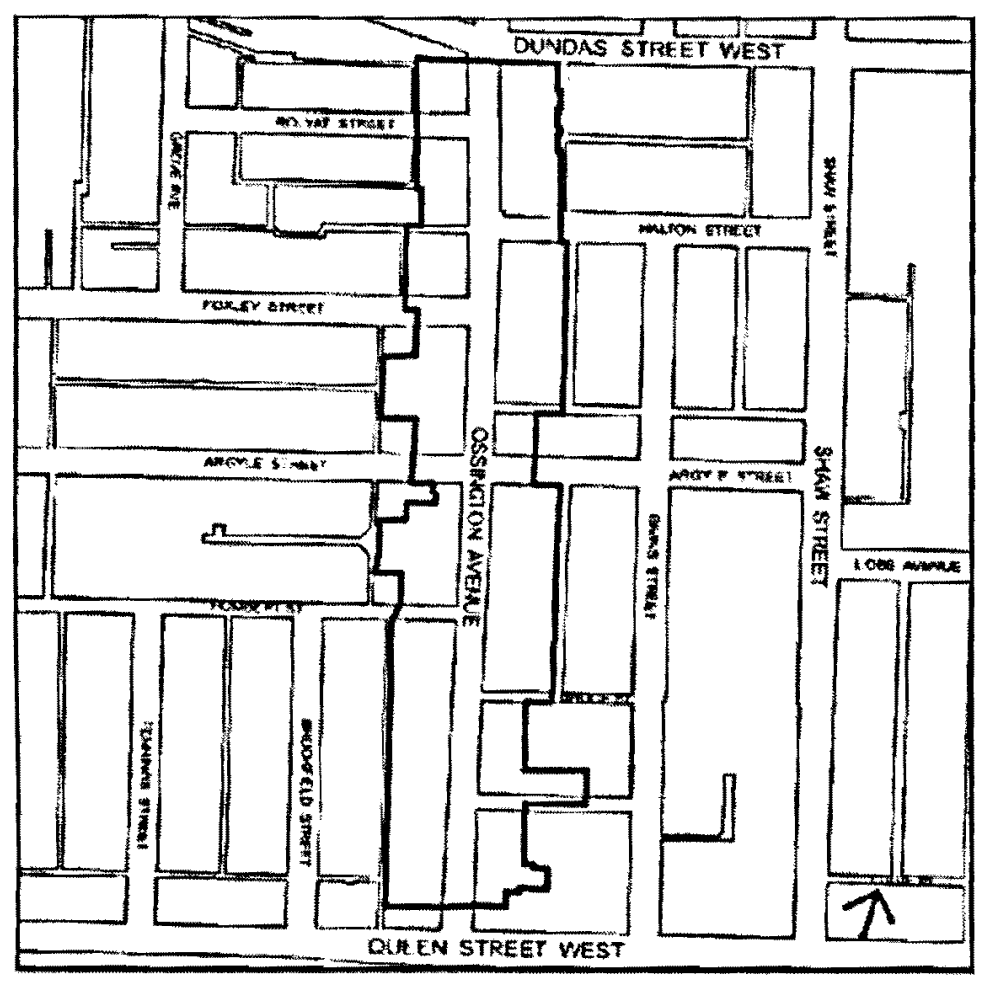

Figure II. Ossington Restaurant Study Area. (Source: City of Toronto, 2009a)

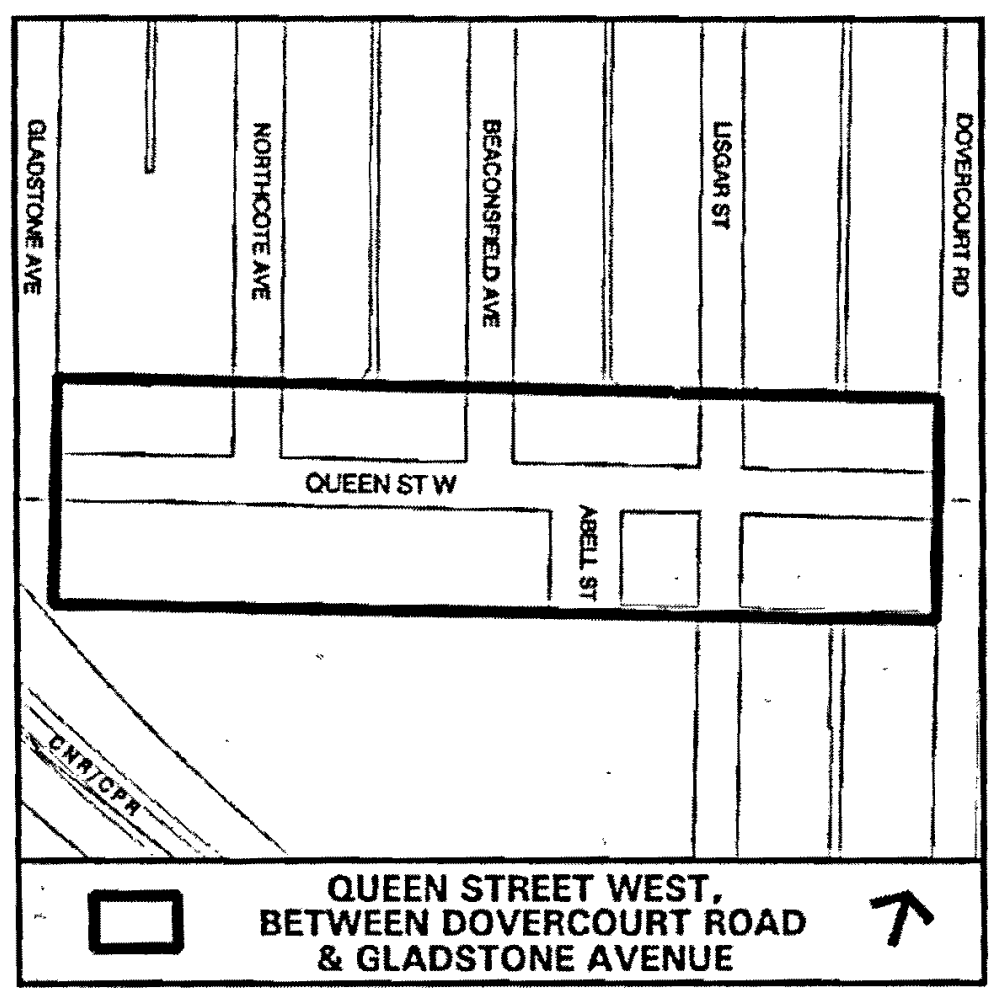

Figure III. Queen Street West Restaurant Study Area (Source: City of Toronto, 2009b) 
petition requesting that action be taken to mitigate the nuisance. In the instance of the Ossington study, an interim control bylaw was enacted in May 2009, "prohibiting restaurants and similar uses for a period of one year within the study area to allow City Planning sufficient time to conduct a study" (City of Toronto, 2009a, p. 3).

Both streets are major arterial routes with a traditional Main Street character: commercial use on the main floor and residential units above. Both streets also contained buildings formerly used for industrial purposes. Both avenues were and remain zoned for mixed-use (City of Toronto, 2009a; City of Toronto, 2009b).

As the Queen West study states, the avenue has been the site of "revitalization," with many previously vacant storefronts gaining new tenure from a variety of uses, mainly art galleries, restaurants, and bars (Rankin, 2008; City of Toronto, 2009b). At both community consultation meetings, residents concerned with the new developments were not opposed to the revitalization of commercial uses; rather they desired a greater diversity of businesses on the strips rather than the concentration of restaurants, more like late-night drinking establishments, that had opened. Residents complained that this proliferation of bars generated excessive noise at night, disruptive behaviour on the street, and vandalism. In addition to the residents' concerns, planning staff articulated in both instances that the larger restaurants tend to attract people on a more "regional" basis (that is, from outside the neighbourhood). While this type of district might be appropriate for a more central location, planners argued that as avenues adjacent to residential neighbourhoods, this type of bar district is incompatible.

Residents in both instances expressed interest in having a cap put on how many bars may be opened in the area, or a minimum distance between bars (other large cities 
enforce such restrictions) (City of Toronto, 2009b). However, the final product of both studies were zoning bylaw amendments that reduced the as-of-right size and density permissions, as well as a ban on certain ancillary uses that characterize late-night bar establishments, such as dance floors and DJ booths. Also amended was the prohibition of any new rear-yard patios, restrictions that "any future patio flanking a residential street be restricted to $50 \%$ of the depth of the building in which a restaurant is located" (City of Toronto, 2009a, p. 8; City of Toronto, 2009b, p. 10), and tighter soundproofing regulations.

One of the major issues expressed by planning staff about this issue was that the existing zoning bylaw governing this area of the city had no specific definition for a bar or late-night drinking establishment. Therefore, restaurants and bars must be treated the same way. The Queen West final planning report states "to amend the zoning bylaw to include such a definition would in staff's opinion, be inappropriate" (p. 6). It doesn't explicitly state why it was inappropriate, but rather that it would be difficult to do so under current alcohol licensing provisions that require all establishments serving alcohol to serve a minimum of five entrée items. With no separate categories for bars from restaurants, the planning department is unable to ban such types of businesses from a neighbourhood without also banning regular-operating restaurants, which faced no opposition from community members. Planning staff stated that restricting the ancillary uses and size should help deter larger bars from opening, addressing the concern of the residents. Aside from this absence of a definition for "bar" causing a problem in addressing the residents' issues, another problem with the final decision is the fact that the residents' concern for more diverse use could not be addressed through zoning. Land 
use planners can only provide permissions and restrictions, but have no role in who can use the space.

Reactions to the city planning staff overall was negative. At the community consultations regarding the final decision, members of the public indicated that the decisions did not address their initial concerns, but rather hindered existing and new businesses with stricter regulations and more administrative red-tape (Kennedy \& Lu, 2009). In the case of the Ossington study, the bylaw amendment was appealed to the Ontario Municipal Board, but later lifted before it reached a hearing (Ontario Municipal Board [OMB], 2010; Stavrou, 2010). The Queen West bylaw amendment faced one appeal by a bar owner who had already submitted a rezoning application. However, instead of enforcing the new amendments and risking going to the Board, the city exempted that property from the amendments (J. Houston, personal communication, February, 2011). Amendments to both bylaws have been incorporated in the city's new harmonized zoning bylaw that has been approved by council, but which also was appealed to the Ontario Municipal Board and has recently been rescinded (Zoning Bylaw 1156-2010; Moloney, 2011).

As mentioned earlier, this event is characteristic of gentrifying neighbourhoods, but not exclusive to them. In evaluating the city planning department's response, questions one can ask that are not specific to gentrifying neighbourhoods might be: Did the planner's decision accurately address the concern? How does this planning decision affect the future livelihood of the area? In the context of the changing demographic outside the area, one might also want to explore: Who do the changes cater to? Was the 
response by the planners equitable? Who benefits from the final planning decision? How does the change affect the diversity of the area?

It is difficult to answer these latter questions pertaining to gentrification, as the built form restrictions have little control over what sort of businesses open up, but rather-as stated by the planners-are only able to control the size and ancillary uses of establishments. While highly criticized by residents of the neighbourhood and represented by the media as the city stopping "growth" and "fun" (Kennedy \& Lu, 2009; Gee, 2009), I would argue the placement of the interim control bylaw was warranted and represents the planning department taking a responsible role of inspecting new development in the face of rapid change. I do, however, agree with the public's point that the zoning bylaw amendments do little to address the more important issues facing the area, such as business diversity and ensuring the commercial character serve the purpose of the area, as opposed to the region. I will revisit this limitation of the planners in the analysis section later in this paper.

\section{B. The West Queen West Triangle}

The West Queen West Triangle (the Triangle) is an area of land bounded by Dovercourt Road to the east, Queen Street West to the north, and the CN railway corridor to the southwest (see Figure IV). Adjacent to the $\mathrm{CN}$ rail corridor, the Triangle lands were traditionally used for industrial purposes, but by the end of the $20^{\text {th }}$ century these industries had mostly left the area (City of Toronto, 2006b). Following the progression of gentrification of Queen West westward at the end of the 1990s, by the early 2000 s, the residential areas adjacent to the Triangle had seen an influx of young people, artists, and 
other members of the "creative class," (a term coined and popularized by Richard Florida [2002], meaning those professions who are "purveyors of creativity," such as engineers, architect, designers, writers, and other types of artists). These new types of residents were also reflected in the commercial makeup of the West Queen West area, with the opening of bars, cafes, and many art galleries (City of Toronto, 2006b). The area was recognized as a "nucleus" for the City's creative industries (ibid.), and by 2005 , the commercial properties on Queen St. between Bathurst and Dufferin established the West Queen West BIA, branded as the Art and Design District BIA ("Our BIA", 2011).

While the areas abutting the undeveloped Triangle had been home to the new class of residents, the Triangle itself was mostly vacant, with only one building within the Triangle,

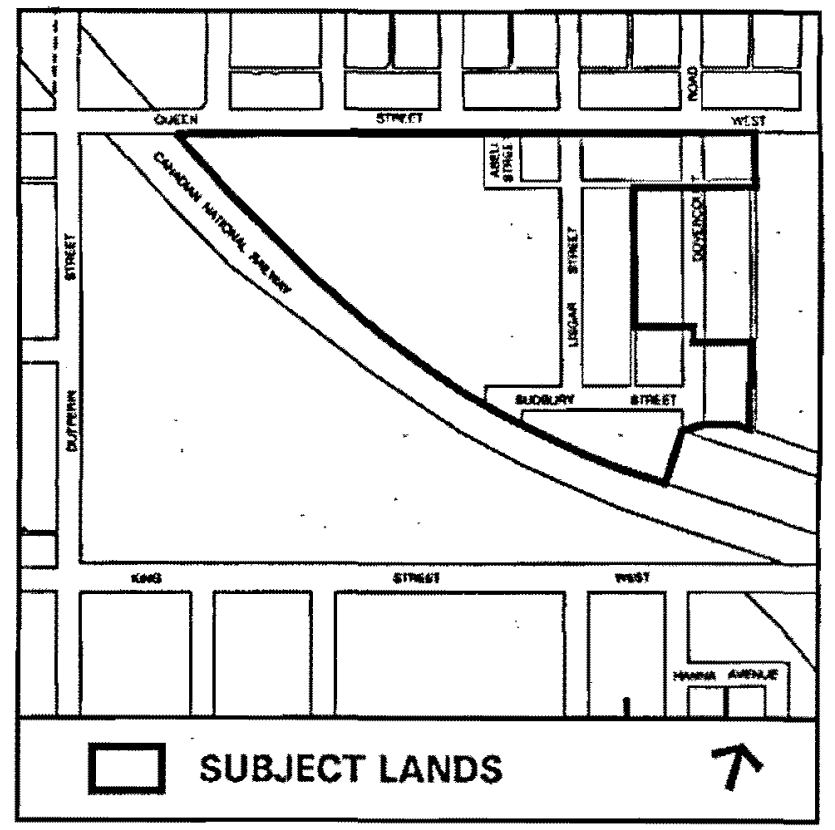

Figure IV. West Queen West Triangle (Source: City of Toronto) 48 Abell St., home to residents in the form of illegal live/work units (Preville, 2007). After the opening of the Drake Hotel in 2005 and the Gladstone Hotel shortly thereafter, the area drew attention from developers wanting to build new condominiums in the mostly vacant lands. This included the demolition and redevelopment of 48 Abell Street, although this property was later saved from demolition. Interest in the Triangle gained city-wide attention in 2006 when three condo developers took the city planning department to the Ontario Municipal Board after its refusal to enact a proposed official 
plan and zoning amendment applications to permit their proposed developments in the time allotted by law (OMB, 2007a). In addition to the dispute between the city planning department and the developers, certain members of the community, through the newly formed organization Active 18, became involved in the process, conducting community visioning charettes, speaking at the hearings as an official party, as well as participating in a working group engaging all parties. This working group process was recommended by the OMB during the hearing in order to come to an agreement as soon as possible. The Active 18 consisted of members who are well known in Toronto's city-building community, such as Margie Zeidler and Jane Farrow, and had the assistance and support of Ken Greenberg of Greenberg Consulting, a well-respected planner in the city (Active 18, 2006; Hertz, 2007). Active 18 identified themselves as YIMBYists, standing for "Yes in My Backyard," in an attempt to distance themselves from the common perception of residents' associations as NIMBYists (Not In My Backyard), making it clear at many points throughout the process that they were not opposed to development in the area (Duncan, 2006).

After a 35-day hearing ending in January 2007, the OMB supported the developers' appeals and approved the condo construction. However, the permitted developments were granted under the condition of, in turn, providing a number of community benefits, such as a new public park, affordable live/work units for artists, and funding to other forms of community arts development (OMB, 2007a; City of Toronto, 2007). Particularly notable was the plan for a private developer to sell a number of units in one of the condominiums to Artscape, a not-for-profit organization that acquires properties and rents them to artists at below-market rates. At the time these units were 
completed and rented, such a partnership was unprecedented ("Background", 2011).

While the allocation of artist live-work units to artists is generally considered an innovative and original endeavor, the overall events that occurred in the Triangle have been met with much criticism from those involved, as well as from outsiders (Preville, 2007; Hume, 2007; Mays, 2007). Active 18 and some urban critics still believe that the height of the approved new development, even after slight alterations, is incompatible with the built form and character of the neighbourhood, and is not of high enough design quality, especially in an area dubbed the Art and Design District (Mays, 2007; Preville, 2007). One of the major concerns among stakeholders (as is the case with all studies in this paper), was that the very reason the area became of interest to developers-a social space for artists and a unique lively neighbourhood—would be gone once the new developments were built (City of Toronto, 2005; City of Toronto, 2006a). Because this study is being published just as these developments are finishing construction, only time will tell if these concerns are borne out.

The OMB hearing regarding the Triangle has been discussed and referenced in recent years in relation to a debate around the relevance of the OMB. It is beyond the scope of this study to consider this debate; I am concerned, rather, with understanding the objectives of the city planning department and how they conducted themselves throughout the process. Therefore, I focus on two aspects of particular relevance to the topic of planning for neighbourhood changè: first, the City and Active 18's attachment to the "creative cities" theory throughout the process, and second, the heightened insight this case gives to the issue of temporal factors in planning for change, more specifically, 
the need for pre-emptive, comprehensive, legally binding planning documents, and the city's lack of organization and staffing for achieving this.

\section{The Protection of a Creative Nucleus}

As discussed earlier in this paper, critics of gentrification have implicated municipal governments in recent years in the implementation of policies that support neighbourhood upgrading. However, in the case of the West Queen West Triangle, the city planning department was clearly interested in protecting the area's artist population and creative workers, and in retaining properties of creative economies. While this is a good case for evaluating how the planners attempted to protect neighbourhood assets in a gentrifying/gentrified neighbourhood, I first want to bring up a critical perspective in response to what exactly was being protected, which might better put into context when the planning department seems to be interested in mitigating neighbourhood change.

The role of the artist has been explicit in discussions of the process of gentrification since the discourse began. In traditional stage models, artists are often key actors in the early stage of gentrification, attracted to an area due to its cheap rent and neighbourhood characteristics of diversity and acceptance (Zukin, 1982). However, there is more of a debate surrounding whether or not artists should be regarded as instigators of, or rather victims of, the process. In her article from 1984, Damaris Rose was one of the first writers to speak about the "marginal gentrifier," that is, a gentrifier who migrates to an area out of necessity (due to family structure or low income) but still acts as an agent of neighbourhood change. For the most part, Rose's discussion of the marginal gentrifier takes the blame away from those who move to an area for cheap rents out of 
necessity, and rightly so. It is my opinion that no one should be blamed for wider sociopolitical processes (such as gentrification) merely by moving to an area they want or need to move to. Rather, it is the responsibility of politicians and policy makers to provide sufficient spaces to accommodate all members of a population.

Another influential voice on the topic of artists in the process of gentrification is Sharon Zukin, a New York sociologist who, in her work Loft Living (1982) brings to light the power of bohemian culture in transforming an area. To Zukin, the way artists alter the image of a neighbourhood and how the market and policy-makers market this "an artistic mode of production," is crucial in the wider process of gentrification; the visual signifiers of artist development become appropriated by real estate marketers and other parties interested (through marketing and image-making) in further transforming a neighbourhood. This type of appropriation, I posit, is illustrated through the labeling of the West Queen West area as a "creative nucleus" (City of Toronto, 2006b) and as the Art \& Design District (ibid). One of the primary concerns surrounding the proposed developments was to maintain the area's role as a place where artists gather, both in livework spaces, but also in the commercial spaces that act as the public face of the artist. community (ibid). In a final staff report to council, the planning staff stated that West Queen West is a "unique" area that shows "what the creative city has to offer to residents of the world" (Ibid). This concern with maintaining and marketing the area as a creative nucleus resembles the appropriation of artistic production presented in Zukin's analysis of gentrifying areas.

While I by no means discredit the importance of artists and creative economies in urban development, my purpose is to simply point out that the planning staff in this case 
seem unevenly concerned with protection and retention of artist housing and commercial space rather than the community at large - community members who inhabited the area far before the in-migration of artists and other gentrifiers. It seems as if the objectives of the city planning documents were unevenly protecting only those community members who were valued economically.

In the early 2000s, Richard Florida's work on the creative class-which states cities with a substantial population of creative workers yields wider economic successhad been gaining traction worldwide, and the City of Toronto was fast to latch on to his theory, with the adoption of city-wide planning documents devoted to strategies protecting this sector (AuthentiCity, 2008). The Creative Class theory has been met with its own criticisms that point out the exclusionary dimensions to its model (Peck, 2005; Rankin \& Delaney, 2011; Lees et al. 2010; see introduction to Part Six) and while I caution anyone to be healthily critical of any "of-the-moment" social theory, it is not my intention to completely nullify its merits. Rather, I simply wish to illustrate that in the context of this area, just a decade earlier, the City of Toronto government was accused of contributing to the removal of affordable housing for lower-income residents and people living with mental illness through regulation changes affecting rooming houses in Parkdale, a low-income neighbourhood adjacent to the Triangle (Slater, 2004).

Another example of the city's bias toward the creative class was their valorization of the Drake and Gladstone Hotels, which were major institutions that changed the face of the neighbourhood and were catalysts for the Triangle development. City staff reports and presentations from community consultation meetings regarded both hotels as "best practices" of creative social space, touting them as major neighbourhood assets (City of 
Toronto, 2006b, p. 8). The reports and presentations do not mention the major displacement of marginal residents who occupied the hotels as permanent housing that occurred when these hotels were developed, even though the Gladstone took great measure to prevent this ("Last Call", 2007).

My criticism of the city planning department in this case is not that the city has historically not had a stake in the retention of affordable living. Conversely, current and past official plans explicitly outline affordability as an issue. What I am saying is in this particular case, which is reflective of the contemporary manifestation of gentrification as evidenced through the gentrification literature, planning practice seems uncomfortably linked to an "in mode" and inequitable social theory. Further, I am not criticizing the city for wanting to protect artist space; I am criticizing the city for the uneven valorization of a class and space that is viewed to have an economic return. I suspect that the city and others might counteract my criticism by arguing that affordable housing is a citywide issue, while the creative character of West Queen West is unique to the area. This exploration, I believe, is deserving of its own study, and I encourage a deeper exploration into it.

Temporal Issues and the Need for Anticipatory \& Preemptive Plans

Suspending this critical perspective, I view the Triangle case as a rich opportunity by which to evaluate the preparedness of the city planning department to address the potentially detrimental effects of a number of major developments. The Triangle lands were subject to the adopted city planning documents-the former City of Toronto's Official Plan from 1994 and the Garrison North II Secondary Plan—as well as evaluated 
in regard to the 2002 Official Plan which was not approved by the OMB until July, 2006 (OMB, 2007b; City of Toronto, 2011b). With the adopted former City of Toronto's Official Plan, the area was designated low-density, mixed commercial-residential along Queen Street West, and mixed industrial-residential for the rest of the area (City of Toronto, 2006b). The new Official Plan designated the area as a regeneration area to "encourage a broad mix of commercial, residential, light industrial, parks and open space, institutional, live/work and utility uses" (City of Toronto, 2002). According to the Garrison Park Secondary Plan in the new Official Plan (an updated version of the Garrison Common North Part II Plan from the former City of Toronto's plan), the area must undergo a study preceding "significant development." When the three applications were submitted, the city had not yet completed their study of the area, but rather conducted it during the appeals process, and stated this was necessary before they could evaluate the proposals and grant any official plan or zoning amendments. However, in one of the later cases, the OMB states that the individual applications were not large enough to necessitate area studies (OMB, 2007b). In the end, the Board's decision was based on technical legal wordings, and the Board condemned the city for not having had a study or plan for the area in place before the development applications were submitted (OMB, 2007a; OMB 2007b). One of the policies put forward in the city's final area study, a proposed no-net-loss policy for artist live-work spaces, was denied by the OMB, as it was deemed "unclear" by the OMB and considered too ad hoc (OMB, 2007a). In one of the case reports from the $\mathrm{OMB}$ hearings, the Board states their disappointment in the city's planning department for not being better prepared, as the intensification proposals were "exciting" and had the potential to yield positive results. The Board sympathized 
with the need to retain artist live-work units, and although denying the proposed no-netloss policy, assured that at-grade use in all development was allocated to commercial or live-work artist space. While the city did gain benefits through section 37 benefits (section 37 refers to the section of the Planning Act regarding bonus provisions, where a developer is permitted heightened density permissions in return for providing community benefits), these were finalized subsequent to the OMB hearings and could have resulted in a number of outcomes.

In a thorough and well-researched piece by Philip Preville (2007) for Toronto Life, a popular city magazine, the late Ted Tyndorf, the city's chief planner of the time was interviewed on the topic of the Triangle proceedings. A major issue in the face of the city's ability to properly prepare for an area's redevelopment, Tyndorf explains in the article, is the city's staffing restrictions and inability to take time to devote to visionary planning, such as an area study for the Triangle. Rather, the city staff must spend most of their time reviewing and approving development applications (Preville, 2007). As this understaffing speaks to the budgeting restrictions the department operates under, the planning staff should not be blamed as scapegoats for the ad hoc planning that occurred in the Triangle case. Rather, this points to major structural issues and municipal government priorities that should be evaluated by city council and the mayor. Much as the planners in this case might be accused of being proponents of a social trend associated with neo-liberal restructuring (the creative cities theory), the inability of the planners to have sufficient plans in place illustrates how the planning department here has also been victim of this neo-liberal restructuring. Through inadequate funding of their 
department by the municipal government, more power has been shifted to the private sector.

More specific to planning for areas undergoing the gentrification process, this inability to act in a preemptive manner is particularly troubling. The gentrification process tends to occur at a rapid pace (Jacobs, 2001) and therefore requires careful attention to development trends and a quick, flexible reaction by city staff. Kennedy and Leonard (2001) point out that the time required for policy to be written, compiled, and adopted is often too lengthy in the face of gentrification that is so fast-paced. The Triangle case exposes major structural flaws-including lack of funding from the municipal budget, and lack of support from the OMB - that resulted in insufficient time for the planning and vision required to be done and adhered to by developers. While one may argue it is difficult to determine where exactly great development pressures will be, there are many indicators of where an area will gentrify, such as proximity to downtown, city-wide gentrifying patterns, historical building stock, and more ${ }^{4}$ (Kennedy \& Leonard, 2001). Further, an area such as the Queen West Triangle, with hectares of underdeveloped land on a popular section of a city's main downtown street, should have been an indicator in itself.

In conclusion, the events that occurred in the West Queen West Triangle demonstrate that the public sector planner is deeply involved in trying to guide new-build development in a gentrifying/gentrified neighbourhood. The case reveals a number of issues, including the caution of a more socially holistic approach for affordable housing, as well as for comprehensive plans that can obtain legal status before major development occurs. Further, it exemplifies two tools available to the planner in Ontario to obtain

\footnotetext{
${ }^{4}$ Kennedy \& Leonard provide a thorough list of indicators for anticipating gentrifying neighbourhoods.
} 
benefits and mitigate incompatible change: Section 37 benefits and innovative partnerships between private developers and not-for-profits.

\section{The West Queen West BIA's Urban Development Framework}

The last intervention I examine is considerably different than the previous two, in that it involves planning activity by parties other than the city's planning department, through a mechanism not elsewhere associated with the gentrification process: a private consulting firm's production of a development framework under contract to the West Queen West Business Improvement Area (BIA).

A set of reference guidelines might seem like a minor intervention in the larger picture of land use, zoning regulation, and urban policy. However, I examine the creation of such guidelines in this paper because it illustrates yet another way the urban planner can be involved in neighbourhood change by addressing issues of built form. In the case of the West Queen West Urban Development Framework, it also interestingly places the BIA - an organization traditionally associated with facilitating gentrification—as a party opposed to the process (albeit, partially opposed). It may be difficult to assess the "effectiveness" of a set of guidelines, yet their production presents some interesting questions in terms of planners and the gentrification process. First, regarding the role of BIAs in the process, and second, through such guidelines, one can examine the relationship between built form and diversity, affordability, and neighbourhood character. 

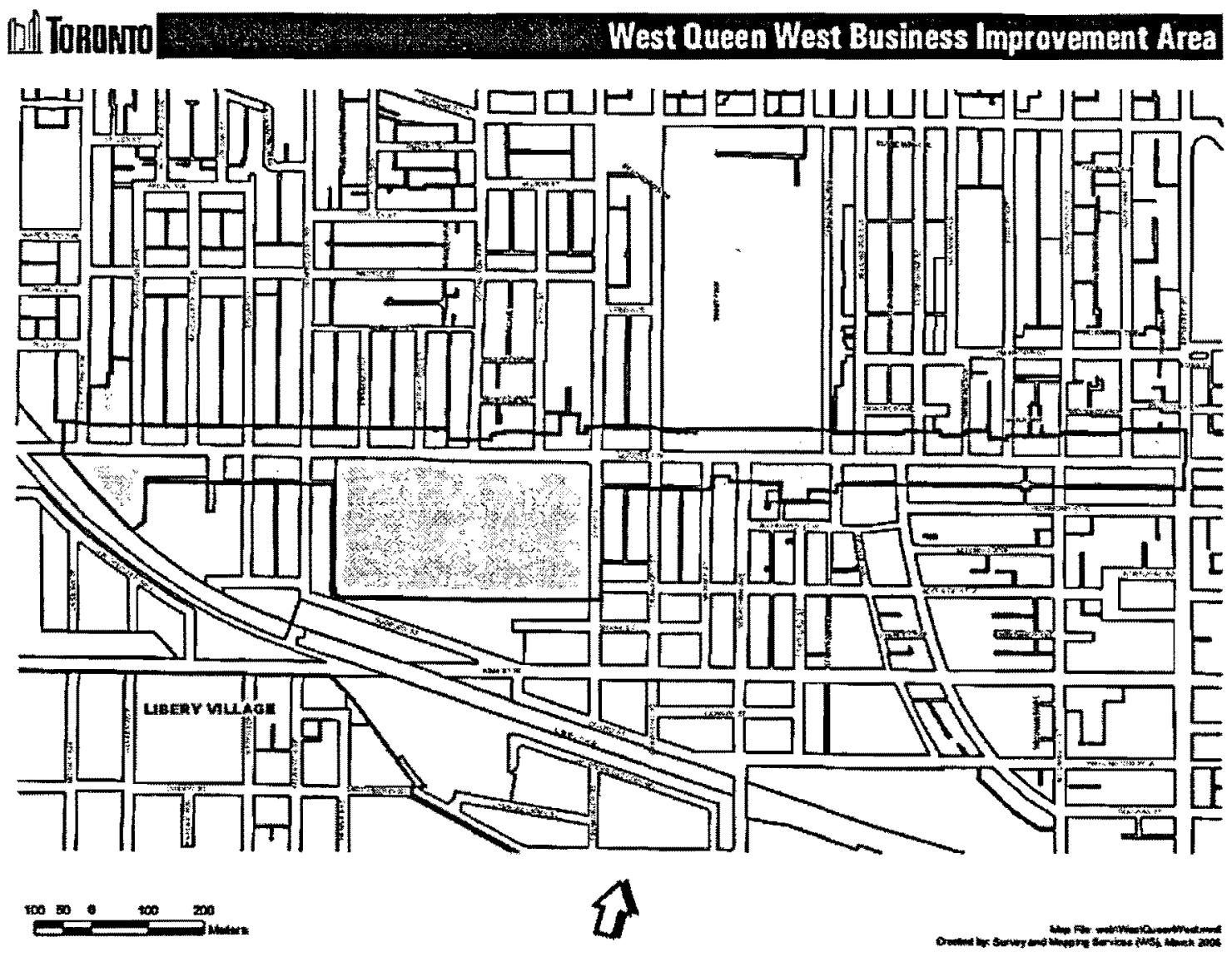

Figure V. Boundaries of the West Queen West BIA (Source; City of Toronto)

\section{The West Queen West BIA}

The West Queen West Business Improvement Assöciation (BIA) is an association of business owners, recognized and in partnership with the city, in the Art \& Design District - the collection of businesses along Queen Street West in the area bounded by Bathurst Street to the east and Gladstone Avenue to the west (See Figure V). The western BIA boundary is the commercial component of Queen Street West that is the northern border of the West Queen West Triangle. The BIA was approved by city council in November 2005, around the same time the Triangle elicited interest from developers. As an observer, it seems the BIA's role in branding the area was surely one significant step 
in the process of gentrifying the area to the next stage in the traditional stage model process, reflective of Zukin's (1982) "artistic mode of production," where cultural identification becomes an important aspect of the gentrification of an area, or of a BIA "packaging" a cultural/neighbourhood identity (Hackworth \& Reckers, 2005). However, based on the concerns raised by BIA and resident members in the creation of the guidelines, it is clear that the members of the BIA were wary themselves of the gentrification process's later stages, primarily the influx of international retailers and big box retailers (Planning Partnership, 2009a).

The resistance to certain aspects of gentrification on the part of a BIA is interesting, as it contradicts the general understanding of a BIA's role in the gentrification process. As the BIA model has gained traction globally over the past four decades, the model has faced scrutiny by critical urban theorists regarding issues of "democracy, accountability, and regulation of public space" (Hoyt \& Goppal-Agge; 2007). As the BIA model privatizes functions traditionally held by the public sector, they are recognized as one of the many governmental bodies associated with neo-liberalism (Delaney \& Rankin, 2011). The proliferation of BIAs can be linked to the policy-supported view of gentrification because one of the primary purposes of a BIA is to "clean up" an area. While property value increase per se is not the goal of BIAs, economic development is, and as an area upgrades, so do property values, resulting in higher rents and displacement.

As already mentioned, commercial tenants are even less likely to own their property than residents are (Jacobs, 2001), so commercial displacement is a major issue, although often not recognized as one. This phenomenon is usually framed as merely an 
aspect of competition in the marketplace. As a result of area upgrading through beautification and other clean-up activities, BIAs might be seen as essentially actors in the gentrification process, defined by their objectives of neighbourhood upgrading ${ }^{5}$. Because of the displacement this may cause, however, they have traditionally been criticized by gentrification academics as such. However, Delaney \& Rankin (2011) and others (Mazer, 2009) have expressed the potential for BIAs to act in a more positive role, as community facilitators in the process of neighbourhood change. As a community-level governed board, BIAs hold the potential to address and react to change in a more effective manner than levels of government that oversee larger jurisdictions. Delaney \& Rankin caution, however, that the success of BIAs to facilitate ethical neighbourhood development is dependent on many factors concerning appropriate partnerships with residents' associations and sufficient monitoring by the municipal government.

\section{BIAs and the Development Process}

Toronto was the home to the first BIA in the world, and currently has 71 within its boundaries (City of Toronto, 2011a). BIAs in Toronto range from casual associations with modest operating budgets to powerful multi-million dollar enterprises (Ministry of Municipal Affairs \& Housing [MMAH], 2010). Over the years, the roles and activities of the Toronto BIAs have grown. Once solely responsible for streetscape beautification and marketing, the BIAs are becoming increasingly involved in the wider development process and major urban development projects. For example, the Bloor-Yorkville BIA was heavily involved in terms of visioning and governing the Bloor Street

\footnotetext{
${ }^{5}$ That business owners themselves are part of an association that might later on displace them might seem odd, though a study by Rankin (2008) exposes the heterogeneous nature of BIA membership and the tensions and problems as a result of forced membership.
} 
Transformation Project and fully funded it (City of Toronto, 2011c) while the Downtown Yonge BIA had similar involvement above and beyond traditional BIA roles with the evolution of Yonge-Dundas Square (Milroy, 2009, see chapter six).

The city's largest BIAs - the Bloor-Yorkville BIA, St. Lawrence Market BIA, and the Downtown Yonge BIA - have begun to contract with private planning and urban design firms to produce development guidelines (also known as urban design guidelines or frameworks) (Ashton et al., 2010). These firms lead, facilitate, and create the framework, and represent expert input. The BIAs can use these frameworks to comment on development and site plan proposals during the development approvals process and when inviting input from outside parties on development applications. Such a framework is a reference tool to better communicate a BIA's vision during this process, but the document also has the potential to be adopted by city council to be used in a similar manner-as a tool of reference within city departments ${ }^{6}$ (Ashton et al, 2010; Madi, personal correspondence, November 2010). Through my research, it seems Toronto is the only city in North America with BIAs that have produced such documents. Research does show, however, that increased involvement of BIAs in the urban development process traditionally led by the public sector is most certainly not exclusive to Toronto (Zukin, 2010 , see chapter 6 on Union Square).

The West Queen West Development Framework

\footnotetext{
${ }^{6}$ There is little public documentation on this city's adoption of such documents. However, a contact at the West Queen West BIA mentioned the guidelines were undergoing a process of becoming adopted by city council. Similarly, personal communication with a private planner revealed similar information of development guidelines becoming adopted. The final draft of the West Queen West guidelines simply recommends the BIA gain "support for the vision" through meetings with city staff, not necessarily adoption.
} 
Development guidelines are a set of performance standards for new development concerned with urban design features that affect the public realm (such as height, massing, street-wall, design details, etc.). They are used to guide development applications and to provide overall direction for an area with regard to built form. While all development guidelines present recommendations for future development, the need for guidelines can arise out of different purposes (Ashton et al, 2010). For example, some guidelines focus on mitigating the negative effects of high-rise development due to intensification targets, while others-such as the West Queen West BIA's-are created out of a response to the threat of an influx of international retailers and as a means to protect its urban character. Further, documents tend to outline existing assets of a neighbourhood worth protecting and enhancing, and thus will include a list of heritage buildings, landmarks, and other buildings of interest.

As stated, the development of the West Queen West Urban Design Framework is the only planning intervention I examine in this study concerning private sector planners ${ }^{7}$. The BIA contracted a private planning firm, the Planning Partnership, to create and facilitate a vision for future development in the BIA area. The firm provided their expertise on urban design, as well as conducted a number of interviews with BIA members, members of resident's association groups, and the City (Madi, personal communication, 2011). As well, the firm conducted a community visioning process that helped outline the issues and directions for the framework (Planning Partnership, 2009b).

Documents from the process shed light on key issues facing the BIA, particularly the role of the BIA as an actor in the gentrification process. Interestingly, two of the

\footnotetext{
${ }^{7}$ Private planners, acting on behalf of development applications, were involved in the Triangle case. Their objectives, however, are not discussed in this study. Rather, 1 focused on the city planning department's role in that case.
} 
issues identified during the creation of the guidelines were "Implications of Gentrification" and "Areas in Need of Revitalization" (Planning Partnership, 2009a). The process's focus on both of these issues show that the BIA is not opposed to change, but rather, is focused on neighbourhood change evolving in a way that is compatible with and complementary to the area's existing character that have made it a popular area in the city. The final guidelines present a set of guiding principles and design standards reflective of most contemporary neo-traditionalist design ideals. However, the guidelines stress that it is particularly important to retain heritage attributes, a pedestrian-oriented retail environment (composed of a low street-wall and fine-rhythm store frontage), and superior design as exemplified in the city's Art and Design District (Planning Partnership, 2009b). Further, the document stresses the need for new development to respond to the needs of residents' and visitors alike (ibid.).

Since the framework's completion in 2009 , the document has only been used as a point of reference. However, as this paper is being published, the director of the BIA has indicated that the organization is in talks with the city planning department to have it adopted as a reference document within city departments (Rob Sysak, personal communication, 2011).

Analysis of the Urban Development Guidelines

As a relatively new document, and as a fairly informal one, it is difficult to evaluate the efficacy or success of such an intervention. Still, there are a few points and 
questions I find interesting about the BIA's having contracted a private firm to produce this document.

The first is how the guidelines address the threats of gentrification and international retailers by enforcing traditional built form. When Jane Jacobs published her now iconic The Death and Life of Great American Cities, her chapter on the need for old buildings discussed how a variety of building types is necessary to provide a variety of rents. Today, there is less "bite" to that argument, as heritage buildings and an older area's "gritty" character contributes to its popularity and thus higher property values (Zukin, 2010). However, certain real estate principles still apply, and new buildings charge higher rent than old buildings to pay off initial construction costs. To mitigate this price difference, the scale and size of new buildings or storefronts (one of the major concerns of the West Queen West BIA) can affect the affordability of an area (not to mention the experiential elements of an area). Therefore, the provision of a variety of building types exemplifies an important element of how built form regulation relates to affordability and tenure ${ }^{8}$. However, built form can only stiffen property values to a certain extent, and as international retailers restructure to accommodate more urban environments (Agrell, 2011), development guidelines—even if legally. implementedcannot prevent international retailers from moving into an area. They can, however, influence how their presence affects the visual and experiential quality of the area, as well as strengthen the opportunity for others to afford space in the area.

\footnotetext{
${ }^{8}$ Although an example of residential affordability, The City of Vancouver, another city in Canada with major challenges in central city affordability, has recently loosened its restrictions on secondary housing policy to provide smaller units aimed at increasing affordability of inner-city property (City of Vancouver, 2011). This case acts as another example of the relation between built form regulation and affordability.
} 
A second point to consider when looking at the employment of private planners is the level of community and municipal involvement in the process. As a point of reference for the BIA, this framework should not be problematic. However, in place of a city document or avenue study which is conducted in the interest of the community, careful attention should be placed on how much power this document holds in light of its creation by an association working with the primary goal of economic development (if it is adopted by city council). This last point, on community involvement and true representation of the wider public, will be addressed in the next (and final) analysis section of the paper. In the case of the West Queen West framework, it seems there was great consideration for creating a document that included public input, and that the planners created the document in a respectable context. However, this single case does not mean that increased BIA responsibility should not still be met with a suitable level of scrutiny. 


\section{Case Study Analysis}

It is my hope that the review of these three interventions better informs an understanding of the planner's role in neighbourhood change as it relates to gentrification. It does so by unveiling a number of laws, mechanisms, and tools planners can use to better study and plan for neighbourhood change. As well, the interventions allude to cautions and concerns planners must pay attention to when working in such situations. This review also looks at certain limitations that planners face. There are three major points I wish to bring particular attention to: a summary of the tools employed by the planners in the case studies, the limits of dealing with built form, and the need for a nuanced understanding of neighbourhood politics and the importance of thorough community consultation.

\section{Tools Available}

These cases present a number of planning tools which municipal governments and planners can utilize to address issues related to gentrification. These tools serve different purposes—stalling development, communicating objectives, receiving benefits—but all provide ways to steer neighbourhood change in a way that is more socially equitable and the least destructive to the experiential qualities that make an area interesting in the first place.

In the case of the Ossington Restaurant study, council passed an interim control bylaw, ceasing permissions of a certain category of development in a certain area for one year. This hiatus allowed the city's planning office to conduct a study on the area to better assess what sort of changes should occur on the Strip. This and the West Queen 
West Restaurant Study case also provide insight into the relation (and limitation) between zoning controls and space use. By enforcing size limitations, planners were able to mitigate development perceived as incompatible with the area's existing characteristics. The West Queen West Triangle case, again, employs zoning as a means with which to address change. However, while it may not have been the most desirable means of achieving the community's and planning department's objectives, the real source of benefit to the community in this case was provision of density bonusing under Section 37 of the Planning Act. This mechanism allowed the city to collect community benefits to an area-in this case the retention of artist live/work units and funds towards other community creativity initiative.

Further, the partnership between the city, private developers, and Artscape provides an example of a creative coalition between the public and private sectors to provide affordable units as an alternative to the city's conventional housing units. This sort of partnership should encourage innovative thinking about the ownership of buildings or units by not-for-profits with a specific social mandate. Jane Jacobs (2001) also recognized potential in such a model.

Lastly, and somewhat ironically, the development guidelines contracted by West Queen West BIA illuminate what the city planning department needed during the West Queen West Triangle case-a clear, cohesive vision for future development and neighbourhood assets. Although these guidelines were spearheaded by an association acting out of economic interest, they (along with the city's failing in the West Queen West Triangle incident) illustrate the efficacy of a clear, well-communicated vision. And again, this framework illustrates how scale and sizing of built form is one piece in a 
bigger puzzle of promoting affordability and diversity (such diverse building forms must be supplemented with laws regarding ownership funding, rent control, and below-market housing).

All the above tools show that planners and municipal governments do have an interest in mitigating the negative aspects of neighbourhood economic upgrading. It would be useful for a study to look at other jurisdictions to discover whether or not there are other built-form and land-use regulations that provide similar opportunities for communities undergoing such change.

\section{The Limits of Built Form}

While my study reviews these tools used by planners, it also reveals problems or limitations that planners face in addressing other issues related to neighbourhood change. Earlier in the paper I discussed the need for preemptive, comprehensive, statutory documents to be in place before major development occurs, but there are two more issues I wish to discuss. One of these I have already briefly mentioned: the limits placed on planners to only be able to regulate form and use, and their inability to address tenure and the types of businesses that locate in a neighbourhood. I have already discussed the need for a diversity of commercial establishments that cater to different types of users and also how these spaces are more important than just their utility as suppliers of goods. Yet commercial gentrification seems to be one of the most difficult processes to address, as a business's success or failure is seen as dependent only on market forces. Hartman's "right to stay put" is an argument usually discussed in the context of one's home, and much less so in terms of commercial establishments. However, if society begins to recognize the 
value in these businesses, city planners or not-for-profits might be able to assist those that cater to established residents of a neighbourhood.

As BIAs expand their traditional roles as branders, marketers, and stewards of beautification, it may also make sense for BIAs to become more involved in attracting a diverse array of businesses, rather than merely optimizing the experience of those businesses that are already members. It might not be in a BIA's mandate to ensure their membership represents a diverse mix of businesses catering to different income levels. However, because of their partnerships with residents associations and the city, BIAs seem like a reasonable body to carry on work in this spirit. (BIAs tend to keep an inventory of available real estate and have an expert understanding of the business climate in the area.) Further, the municipal government might wish to consider expanding its economic development department to take these needs into consideration. Of course, lobbying for a greater mix of businesses in communities can always be practiced by notfor-profit and grassroots organizations. There is already an emerging discourse surrounding equitable food delivery in areas in need, and I encourage these studies and interested parties to explore possible connections with gentrifying areas that risk losing the businesses and services in their area.

Thoroughness, Fairness, and Community Consultation

Another major issue raised by the preceding cases that I wish to address is the comprehensive representation of neighbourhood residents during community consultation. One of the most problematic dimensions of studying gentrification has been documenting those who are most affected by the process-those who are displaced, often 
mentally ill or low-income residents (Slater, 2005; Rankin, 2008). Some studies (Freeman, 2006; Mazer \& Rankin, 2011) have given voice to these residents, but overall, there is a great deal of ambiguity reflected in how these residents experience gentrification. Carlos Texeira's qualitative study of Little Portugal, within my study area, illustrates this ambiguity, with original neighbourhood residents expressing both a concern about the process, yet at the same time welcoming the gentrifiers and associated changes. Much to the chagrin of some anti-gentrification writers, many original residents in gentrifying areas communicated that they welcomed the impending change; homogenization of retail to some may seem like affordable outlets to others (for a local example, see the controversy surrounding the development of big box retailers near the waterfront in Toronto's Leslieville neighbourhood). This point relates to my argument that a planner must pay careful attention to who is voicing a complaint or concern in opposition to a major development (such as the West Queen West condominiums) or a conflicting land use (such as the proliferation of bars on Ossington Avenue). What I am particularly cautious about is hypocrisy on the part of earlier gentrifiers (such as artists and the creative class) who move into an area and make many changes themselves, but are opposed to later changes. There will be, without doubt, a variety of opinions from residents over neighbourhood change (regardless of how long they have lived in the area), but it is important that planners do all that is possible to recognize the nuances of neighbourhood politics, and to recognize the types of residents who are more easily able to mobilize and create residents' associations.

Because the information of who attends public consultation meetings is confidential, I was unable to access the lists of who attended the community consultation 
meetings. Through informal conversations with the planners involved in the process, I was able to gather some information, though the answers were often at odds with one another. One planner mentioned that there was a good representation of the area's older Portuguese residents, while another mentioned how difficult it was to get these older residents to appear at such meetings. Again, like my other findings, this point of analysis is a concern worthy of further exploration. 


\section{Conclusion}

This study has attempted, through analyzing planning interventions in a single gentrifying/gentrified area, to better understand the role of the urban planner in the gentrification process. By viewing these planning events through the lens of gentrification issues, I've revealed that the planner is able to address certain issues related to the gentrification process. As discussed, built form and land use are only one aspect of urban planning, and because these dimensions do not regulate use or ownership, they might be easily discarded as an area where social justice or equitable development is unrelated. However, built form and land use do have direct linkages to other factors, such as affordability and business opportunities, and decisions made in this regard can have significant effects on neighbourhoods.

There are certainly limitations to my study (due to time and length constraints); as well, many topics I have just lightly touched on are worthy of further investigation.

First, this study would benefit from extensive interviews with the planners in the process of planning in gentrifying/gentrified areas, for a better understanding of their perceived constraints and objectives.

Second, I have not addressed all of the relevant planning events in Downtown West: the Centre for Addiction and Mental Health [CAMH] redevelopment is a significant project that is sure to have serious implications on the adjacent area. The reason I chose to ignore this development is that it is a complex one, heavily loaded with other issues, such as the ethics and politics surrounding services for people with mental illness, and issues related to planning for major institutions. It was my intention to focus this paper on planning interventions in relation to more traditional gentrification. 
Third, while I have identified planning tools used in my specific case studies, it would be beneficial to do a wider investigation into other planning tools available under the Ontario planning system, and create a guide or resource for planners in areas undergoing or about to undergo neighbourhood change. Such a study would be of further benefit if it examined other jurisdictions.

It is my hope that my study fills a certain void in the gentrification discourse and also acts as a defense of the planner in response to critical geographers who have unfairly implicated the planner as a chief actor in the gentrification process (specifically in the recent phase of neo-liberal governance). I have attempted to present a liberal view with both criticisms and recommendations that are beneficial to practicing planners.

It is also my hope that the information provided carries significance outside of the context of gentrifying areas and can help better inform planning practice as it relates to any area undergoing demographic or character change-whether it be upgrading or otherwise. 


\section{References}

Active 18 (2006). Queen West Triangle Design Charette Report. Retrieved April 2, 2011 from: http://active18.org/charrette

Agrell, S (February 19, 2011). Everyone Wants to be Downtown. Even Wal-Mart. The Globe and Mail. Page M.1.

Ashton, N. A. Greenberg, P. Kethesweran, S. Schachar (2010). Shaping the Future of Yonge Street: A Guiding Framework for the Development of Downtown Yonge. [Final Studio Report]. Toronto, ON: School of Urban \& Regional Planning, Ryerson University.

August, M. (2008). Social Mix and Canadian Public Housing Redevelopment: Experiences in Toronto. Canadian Journal of Urban Research. 17.1, pp 82-100.

AuthentiCity (2008). Creative City Planning Framework. Prepared for the City of Toronto.

Retrieved March 20, 2011 from: http://www.toronto.ca/culture/pdf/creative-cityplanning-framework-feb08.pdf

"Background" (2011). Artscape website. Retrieved April 1, 2011 from:

http://www.torontoartscape.on.ca/places-spaces/artscape-triangle-lofts/background-0

Berry, B. (1985). Islands of Renewal in Seas of Decay in P. Peterson (ed.) The New Urban Reality. Washington, D.C.: The Brookings Institute, pp 69-96.

Castells, M. (1983). The City and Grassroots: A Cross-Cultural Theory of Urban Social Movements, Berkeley: University of California Press.

Caulfield, J. (1994). City Form and Everyday Life: Toronto's Gentrification and Critical Social Practice. Toronto: University of Toronto Press

CIP Code of Practice (2004, June 30). Canadian Institute of Planners website. Retrieved April 2, 2011 from: http://www.cip-icu.ca/web/la/en/pa/c59dde35f1184b5e89385e53506c19f8/ 
template.asp

City of Toronto (2002). Toronto Official Plan. Toronto: City Planning Division.

City of Toronto Community \& Neighbourhood Services (2003a). Little Portugal Social Profile 2

- Neighbourhoods Immigration, Ethnicity, Language. City neighbourhood profile.

Retrieved April 3, 2011 from: http://www.toronto.ca/demographics/pdf2/cpa84.pdf

City of Toronto Community \& Neighbourhood Services (2003b). Trinity Bellwoods Social

Profile 2 - Neighbourhoods Immigration, Ethnicity, Language. City neighbourhood

profile. Retrieved April 3, 2011 from:

http://www.toronto.ca/demographics/pdf2/cpa81.pdf

City of Toronto (2005). Community Consultation Meeting Slides. November 16, 2005. Retrieved

March 13, 2010 from: http://www.toronto.ca/planning/

westqueenwest.htm

City of Toronto (2006a). Working Group Meeting Presentation.March 23, 2006. Retrieved

March 13, 2010 from: http://www.toronto.ca/planning/westqueenwest.htm

City of Toronto (2006b). Overall Direction for Redevelopment of the West Queen West Triangle

(Final Staff Report). May 30, 2006. Retrieved March 13, 2010 from:

http://www.toronto.ca/planning/westqueenwest.htm

City of Toronto (2007). City forges partnership with developers and arts community at West

Queen West Triangle (Press Release). City of Toronto website. Retrieved March 13, 2010 from: http://wx.toronto.ca/inter/it/

newsrel.nsf/0/88BE83582BBFF84885257384006576DE?opendocument 
City of Toronto (2009a). Ossington Avenue Restaurant Study Final Staff Report. October 29,

2011. Retrieved April 2, 2011 from: http://www.toronto.ca/elections/pdf/candidatesquestions-planning-ossington 1.pdf

City of Toronto (2009b). Queen Street West Restaurant Study Final Report. December 14, 2009.

Retrieved April 2, 2011 from: http:/www.toronto.ca/legdocs/mmis/2010/te/bgrd/ backgroundfile-25913.pdf

City of Toronto (2011a). About BIAs. City of Toronto website. Retrieved April 2, 2011 from:

http://www.toronto.ca/bia/about.htm

City of Toronto (2011b). About the Official Plan. City of Toronto website. Retrieved April 2,

2011 from: http://www.toronto.ca/torontoplan/about.htm

City of Toronto (2011c). Bloor Street Transformation Complete. City of Toronto website.

Retrieved April 1, 2011 from: http:/www.toronto.ca/bia/gallery-bloorstreet/index.htm

City of Vancouver (2011). EcoCity Initiatives/Ecodensity (website). Retrieved April 1, 2011

from: http://vancouver.ca/commsvcs/ecocity/

Clendening, I. \& A. Greenberg (2010). Downtown Health \& Form: A Literature Review.

Oakville, ON: Town of Oakville. Retrieved April 2, 2011 from:

http://www.oakville.ca/Media_Files/planning10/lo-dosr-litreview.pdf .

Duncan, D. (2006). Yes, In My Back Yard! Spacing Magazine website. October 24, 2006.

Retrieved March 4, 2011 from: http://spacingtoronto.ca/2006/10/24/yes-in-my-back-yard/

El Kalache, S., L. Fang, A. Moriah, L. Rodríguez, M. Tapper (2005). Taking the Pulse: Gauging

Neighbourhood Change in Toronto's Downtown West End. Toronto, ON: Centre for

Urban and Community Studies, University of Toronto. Retrieved April 1, 2011 from:

http://www.urbancentre.utoronto.ca/pdfs/curp/TakingthePulse-204-5.pdf 
Filion, Pierre, Heidi Hoernig, Trudi Bunting, and Gary Sands (2004). The Successful Few: Healthy Downtowns of Small Metropolitan Regions. American Planning Association: Journal of the American Planning Association. 708, 3: p. 328343

Florida, R. L. (2002). The Rise of the Creative Class: And How It's Transforming Work, Leisure, Community and Everyday Life. New York, NY: Basic Books Freeman, L. (2006) There Goes the 'Hood: Views of Gentrification from the Ground Up. Philadelphia, PA: Temple University Press.

Gee, M. (2009, May 30). Don't Mess With Ossington's Success. The Globe and Mail. Page M.3 Glass, R. (1964). London: Aspects of Change. London: McGibbon \& Kee. Hackworth, J. \& J. Reckers (2005). Ethnic Packaging and Gentrification: The Case of Four Neighbourhoods in Toronto. Urban Affairs Review. 41.2, pp. 211-246.

Hackworth, J. \& N. Smith (2001). The Changing State of Gentrification in The Gentrification Reader. London: Routledge, pp 65-76.

Hamnett, C. (1991). The Blind Men and the Elephant: The Explanation of Gentrification. Transactions of the Institute of British Geographers. 16.2 173-189.

Hartman, C. (1984). The Right to Stay Put. In C. Geisler and F. Popper (eds). Land Reform American Style. Totowa, NJ: Rowman \& Allanhead.

Harvey, D. (2008). Right to the City. New Left Review. 53: 23-40.

Hertz, B. (2007). Details trickle out on Queen West Triangle Deal. National Post. October 30, 2007. Retrieved March 13, 2010 from:

http://network.nationalpost.com/np/blogs/toronto/archive/2007/10/30/city-reaches-dealwith-developers-for-queen-west-triangle.aspx 
Hoyt, L. \& D. Goppal-Apgge (2007). The Business Improvement District Model: A Balanced Review of Contemporary Debates. Geography Compass 1.4: 946-958.

Hulchanski, D. (2010). The Three Cities Within Toronto: Income Polarization Among Toronto's Neighbourhoods, 1970-2005 (Published Report). Toronto, ON: Cities Centre, University of Toronto.

Hume, C. (2007, January 6). Boho goes Condo as developers rule Queen West. The Toronto Star. Retrieved online April 1, 2011 from: http://www.thestar.com/article/171439 Jacobs, J. (1961). The Death and Life of Great American Cities. New York: Random House. Jacobs, J. (2001). Time and Change as Neighbourhood Allies. Speech Excerpt published in Ideas that Matter: A Quarterly. 3.2:4-7.

Kennedy, M. \& P. Leonard (2001). Dealing with Neighborhood Change: A Primer on Gentrification and Policy Choices. The Brookings Institute. Retrieved from: http://www.brookings.edu

Kennedy, B. \& V. Lu (2009, November 14). Ossington Growth Problems: Bar Owners, Residents Furious. The Toronto Star. Retrieved April 1, 2011 from: http://www.thestar.com/news/gta/article/725793--ossington-growth-problems-barowners-residents-furious

Last Call at the Gladstone (2007). Producers: Derreck Roemer \& Neil Graham. [Documentary]. Toronto: Last Call Productions.

Lauria, M. and L. Knopp (1985). Towards an Analysis of the Role of Gay Communities in the Urban Renaissance. Urban Geography. 6.2: 152-169.

Lees L, T. Slater, and E. Wyly (2010). The Gentrification Reader. London: Routledge, pp 65-76.

Lees L, T. Slater, and E. Wyly (2008). Gentrification. London: Routledge. 
Lees, L. (2008). Gentrification and social mixing: Towards an inclusive urban renaissance? Urban Studies. 45.12: 2449-2470.

Ley, D. (1996). The New Middle Class and the Remaking of the Central City. Oxford: Oxford University Press.

Mays, J.B. (2007). On Queen West: A mistake in the making. The Globe \& Mail. November 23, 2007. Retrieved March 13, 2010 from: http://www.theglobeandmail.com/real-estate/onqueen-west-a-mistake-in-the-making/article132900/

Mazer, K. (2009). Revitalizing Tired Terms: A Language of Anti-Gentrification Planning. IndyReader (website). Retrieved March 3, 2011 from: $\mathrm{http} / / /$ indyreader.org/content/revitalizing-tired-terms-a-language-anit-gentrificationplanning-by-katie-mazer

Mazer K \& K. Rankin (2011) The social space of gentrification: the politics of neighbourhood accessibility in Toronto's Downtown West. Environment and Planning D: Society and Space 29 (forthcoming), doi:10.1068.d7109

Milroy, B. (2009). Thinking Planning and Urbanism. Vancouver, B.C.: UBC Press.

Mintz, C (2011). Why your great neighbourhood has terrible restaurants. Open File (website). Published March 10, 2011. Retrieved March 12, 2011 from: http://toronto.openfile.ca/toronto/file/2011/03/why-your-great-neighbourhood-hasterrible-restaurants

Ministry of Municipal Affairs and Housing (2010). Business Improvement Area Handbook, 2010. Retrieved March 27, 2011 from: http://www.mah.gov.on.ca/Asset7396.aspx Mitchell, S. (2006). Big-Box Swindle: The True Cost of Mega-Retailers and the Fight for America's Independent Businesses. Boston: Beacon Press. 
Moloney, P (2011, March 24). Back to the drawing board for new zoning bylaw. Toronto Star.

Retrieved April 2, 2011 from: http:/www.thestar.com/news/torontocouncil/article/ 960283--back-to-the-drawing-boards-for-new-zoning-bylaw

OMB [Ontario Municipal Board] (2007a). Decisions 0052, 0053, and 0054. January 10, 2007. Retrieved April 2, 2011 online from:

http://www.omb.gov.on.ca/english/eDecisions/eDecisions.html

OMB [Ontario Municipal Board] (2007b). Decision 1924. July 10, 2007. Retrieved April 2, 2011 online from: http://www.omb.gov.on.ca/english/eDecisions/eDecisions.html

OMB [Ontario Municipal Board] (2008.) Memorandum of Oral Decision Delivered by D.R. Granger on December 20, 2007 and Order of the Board. January 8, 2008. Retrieved April 2, 2011 from http://www.omb.gov.on.ca/english/eDecisions/eDecisions.html OMB [Ontario Municipal Board] (2010). Pl100051: Memorandum of Oral Decision by James $R$. McKenzie on July 13, 2010 and Order of the Board. August 5, 2010. Retrieved April 7, 2011 from: http://www.omb.gov.on.ca/e-decisions/pl100051-Aug-25-2010.pdf

"Our BIA", (2011). West Queen West BIA website. Retrieved April 3, 2011 from: http://westqueenwest.ca/about-us

Peck, J. (2005). Struggling with the Creative Class. International Journal of Urban and Regional Research. 29.4: 740-770.

Planning Act, R.S.O. 1990.

Planning Partnership (2009a). Urban Development Framework Document Meeting (Powerpoint slides). Retrieved April 3, 2011 from: http://westqueenwest.ca/service/west-queen-westurban-development-framework 
Planning Partnership, (2009b). Urban Development Framework. Toronto, ON: The Planning Partnership.

Preville, P (2007). Bedevilled Triangle. Toronto Life. June, 2007. Retrieved online from: http://www.torontolife.com/features/bedevilled-triangle/

Rankin, K. (2008). Commercial Change in Toronto's West-Central Neighbourhoods. Toronto: Centre for Urban \& Community Studies. Retrieved March 3, 2011 from: http:/www.geog.utoronto.ca/people/faculty/rankin/CC-RP214-Rankin-Sept-2008.pdf

Rankin K and J. Delaney (2011) Community BIAs as practices of assemblage: contingent politics in the neoliberal city. Environment and Planning A. 43 (forthcoming), doi:10.1068.a43301

Rose. D. (1984). Rethinking Gentrification: Beyond the Uneven Development of Marxist Urban Theory. Environment and Planning D: Society and Space. 2.1: 47-74.

Sewell, J. (1993). The shape of the city: Toronto Struggles with Modern Planning. Toronto: University of Toronto Press

Slater, T, (2004) Municipally-managed gentrification in South Parkdale, Toronto. Canadian Geographer. 48.3: 303-325

Slater, T. (2005). Evictions of Critical Perspectives from Gentrification Research. International Journal of Urban and Regional Research. 30.4: 737-757.

Smith, N. (1979). Toward a Theory of Gentrification: A Back to the City Movement by Capital, not People. Journal of the American Planning Association. 45.4: 538-548.

Smith, N. (1996). The New Urban Frontier: Gentrification and the Revanchist City. London; New York: Routledge. 
Smith, N. (2002). New Globalism, New Urbanism: Gentrification as Global Urban Strategy. Antipode, 34.3: 427-450.

Statistics Canada (1997). 1996 Census of Canada. Data retrieved online from Canadian Census Analyser (CHASS): http://dc1.chass.utoronto.ca/census/

Statistics Canada (2002). 2001 Census of Canada. Data retrieved online from Canadian Census Analyzer (CHASS): http://dc1.chass.utoronto.ca/census/

Statistics Canada (2007). 2006 Census of Canada. Data retrieved online from Canadian Census Analyser (CHASS): http://dcl.chass.utoronto.ca/census/

Stavrou, P. (2010, November 9). City Lifts Ossington Moratorium: Salt Wine Bar Re-Opens. Post City Website. Retrieved April 1, 2011 from:

http://www.postcity.com/Cityscape/restoronto/November-2010/Salt-Wine-Bar-re-opensafter-city-lifts-Ossington-moratorium

Teixera, C. (2006). Residential Segregation and Ethnic Economies in a Multicultural City: the Little Portugal of Toronto in Landscapes of the ethnic economy. Kaplan, D. H., \& Li, W. (eds). Lanham: Rowman \& Littlefield Publishers

Teixera, C. (2007). Toronto's Little Portugal: A Neighbourhood in Transition: Research Bulletin \#35. Toronto: Centre for Urban and Community Studies, University of Toronto. '

Walks, R. \& R. Maaranen. (2008). Gentrification, Social Mix, and Social Polarization: Testing the Linkages in Larger Canadian Cities. Urban Geography. 29.4, pp. 2494-2625.

Whyte, W. (1988). City: Rediscovering the Center. New York: Doubleday.

Wyly, E. and Hammell (2009). Islands of Decay in Seas of Renewal: Housing Policy and the Resurgence of Gentrification. Housing Policy Debate. 10.4: 711-771. 
Zoning Bylaw 1156-2010 (draft). Retrieved online April 2, 2011 from:

http://www.toronto.ca/zoning/index.htm

Zukin, S. (1982). Loft Living: Culture and Capital in Urban Change. Baltimore: Johns Hopkins University Press.

Zukin, S. \& E. Kosta (2004). Bourdieu Off-Broadway: managing distinction on a shopping block in the East Village. City and Community 3.2, 101-114

Zukin, S. (2010). Naked City: The Death and Life of Authentic Urban Places. Oxford: Oxford University Press. 